\title{
Simplified Expert Elicitation Guideline For Risk Assessment Of Operating Events
}

Ronald Boring

David Gertman

Jeffrey Joe

Julie Marble

William Galyean

Larry Blackwood

Harold Blackman

June 2005

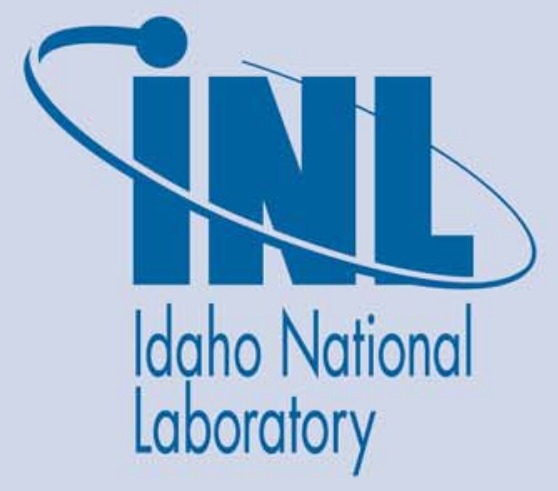

The INL is a U.S. Department of Energy National Laboratory operated by Battelle Energy Alliance 



\section{Simplified Expert Elicitation Guideline for Risk Assessment of Operating Events}

Manuscript Completed: June 24, 2005

Prepared by:

Ronald Boring, David Gertman, Jeffrey Joe, Julie Marble, William Galyean, Larry Blackwood, and Harold Blackman

Idaho National Laboratory

Idaho Falls, Idaho 83415

Prepared for:

Bennett Brady, NRC Program Manager

Office of Nuclear Regulatory Research

Division of Risk Analysis \& Applications

U.S. Nuclear Regulatory Commission

Washington, D.C. 20555

NRC Job Code Y6987 



\title{
ACKNOWLEDGMENTS
}

The following individuals were consulted in the development of this guideline or assisted in the review of this document. We are grateful for the invaluable insights they provided into the expert elicitation process.

\author{
Nuclear Regulatory Commission \\ Pat Baranowsky \\ Bennett Brady \\ Erul Chelliah \\ Mike Cheok \\ Nilesh Chokshi \\ Gary DeMoss \\ Don Dube \\ Russell Gibbs \\ Eli Goldfeiz \\ Jim Houghton \\ Selim Kancartar \\ Steve Long \\ Don Marksberry \\ Pat O'Reilly \\ Sunil Weerakkody
}

ABS Consulting

Bob Christie

Michelle Johnson

Leonard Palko

\author{
Idaho National Laboratory \\ Robert Buell \\ Theresa Flores \\ Cindy Gentillon \\ Bruce Hallbert \\ James Knudsen \\ Patrick McCabe \\ John Poloski \\ Martin Sattison \\ John Schroeder \\ Curtis Smith
}




\begin{abstract}
This report describes a simplified, tractable, and usable guideline within the US Nuclear Regulatory Commission (NRC) for seeking expert opinion and judgment. The NRC has increased efforts to document the reliability and risk of nuclear power plants (NPPs) through Probabilistic Risk Assessment (PRA) and Human Reliability Analysis (HRA) models. The Significance Determination Process (SDP) and Accident Sequence Precursor (ASP) programs at the NRC utilize expert judgment on the rate of failure, human error, and the operability of equipment in cases where otherwise insufficient operational data exist to make meaningful estimates. In the past, the SDP and ASP programs informally sought the opinion of experts inside and outside the NRC. This document represents a formal, documented guideline to take the place of informal expert elicitation. The steps outlined in this report follow existing formal expert elicitation methodologies, but are streamlined as appropriate to the degree of accuracy required and the schedule for producing SDP and ASP analyses.
\end{abstract}

DISCLAIMER. This research was funded by the US Nuclear Regulatory Commission and carried out by Idaho National Laboratory, a US Department of Energy laboratory operated by Battelle Energy Alliance. This report was prepared as an account of work sponsored by an agency of the US Government. Neither the US Government nor any agency thereof, nor any of their employees, makes any warranty, express or implied, or assumes any legal liability or responsibility for any third party's use, or the results of such use, of any information, apparatus, product, or process disclosed in this report, or represents that its use by such third party would not infringe privately owned rights. 


\section{CONTENTS}

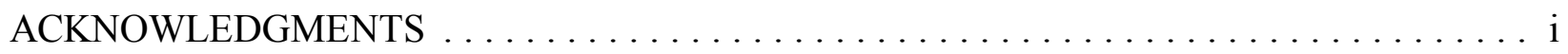

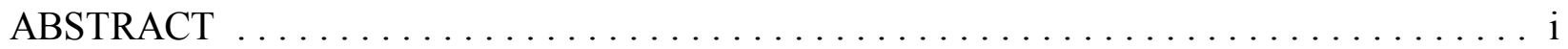

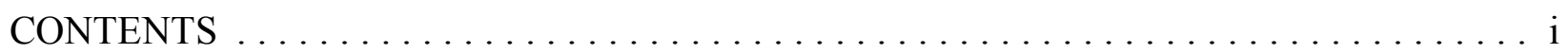

1. INTRODUCTION AND OBJECTIVES $\ldots \ldots \ldots \ldots \ldots \ldots \ldots \ldots \ldots \ldots \ldots \ldots \ldots \ldots$

2. EXPERT ELICITATION GUIDELINE INSTRUCTIONS $\ldots \ldots \ldots \ldots \ldots \ldots \ldots \ldots$

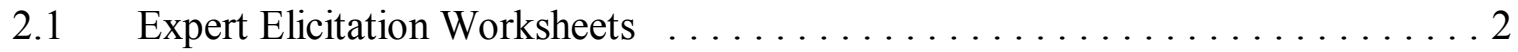

2.2.1 Requirements for When and on What Problems to Use This Guideline . . 2

2.2.2 Requirements for How the Results May Be Used ............. 4

$2.3 \quad$ Expert Elicitation for Hardware $\ldots \ldots \ldots \ldots \ldots \ldots \ldots \ldots \ldots \ldots \ldots \ldots$

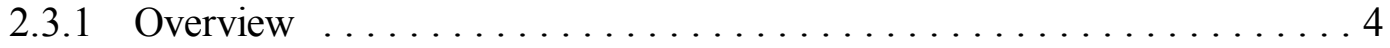

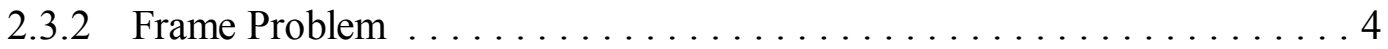

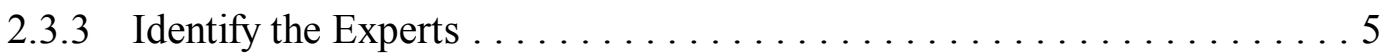

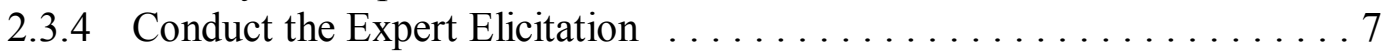

2.3.5 Convene Expert Panel ............................. 9

2.3.6 Aggregate Estimates . ........................ 10

2.3.7 Compute Distribution and Input into Risk Model $\ldots \ldots \ldots \ldots \ldots \ldots$

$2.4 \quad$ Expert Elicitation for Human Error $\ldots \ldots \ldots \ldots \ldots \ldots \ldots \ldots \ldots \ldots \ldots \ldots \ldots$

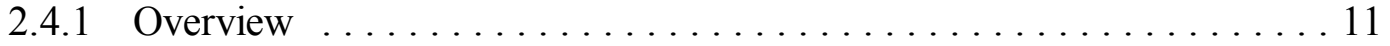

2.5 Notes on SDP, ASP, and Other NRC Elicitation Requirements . . . . . . . 13

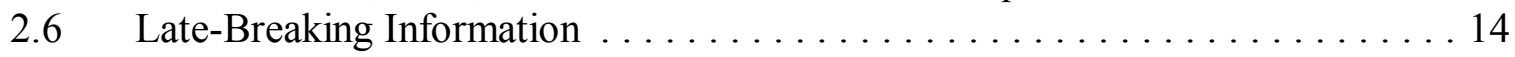

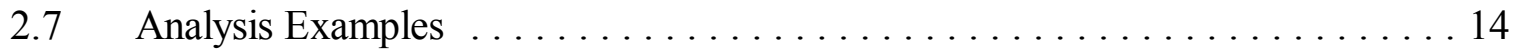

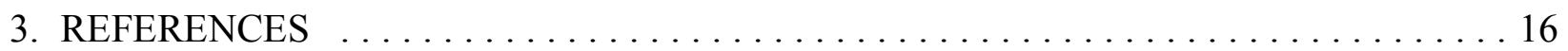

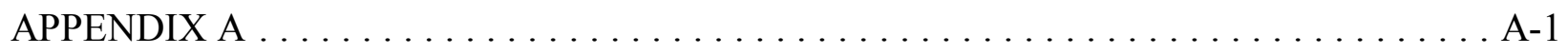

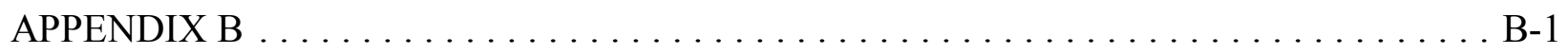

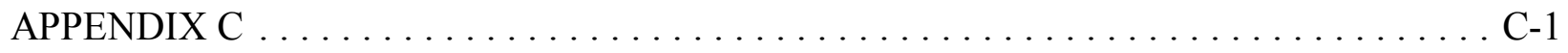

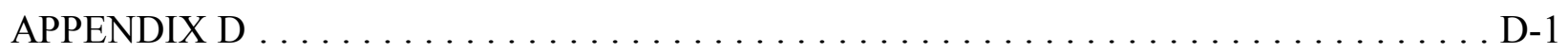

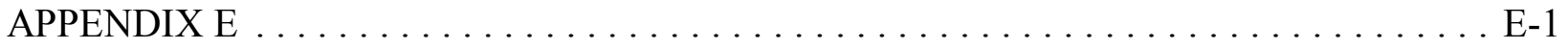

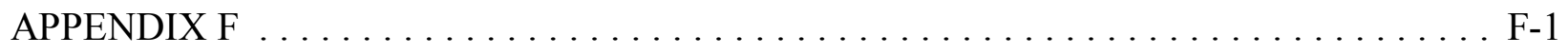

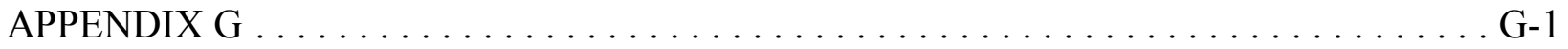




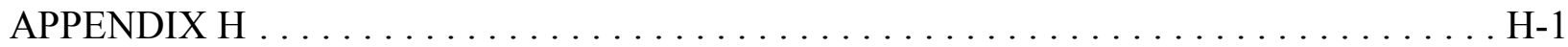




\section{INTRODUCTION AND OBJECTIVES}

The US Nuclear Regulatory Commission's (NRC's) Accident Sequence Precursor (ASP) Program involves the systematic review and evaluation of operating events that have occurred at licensed US commercial nuclear power plants. The ASP Program identifies and categorizes precursors to potential severe core damage accident sequences. An accident sequence precursor is an operating event that is an important element of a postulated core-damage accident sequence. Accident sequences of interest to the ASP Program are those that would have resulted in inadequate core cooling and severe core damage if additional failures had occurred.

As part of the ASP analysis, a determination of equipment functionality or failure rate is often needed. For cases for which there is insufficient operational data to make meaningful estimates, the NRC requires expert judgment on the rate of failure, human error, or the operability of equipment.

An expert elicitation for the purpose of supporting risk assessment involves three components: (i) subject matter experts, (ii) judgments about the likelihood of event occurrence, and (iii) analysts who use these opinions in a risk assessment. The success of expert elicitation hinges on the well-orchestrated interplay of the right subject matter experts using the right information (or the information available) in conjunction with analysts providing the correct method to judge event likelihoods and making the correct inferences based on the expert opinion.

For events that are rare or for which there are little operating data, a series of methods was proposed within the NRC to generate reliable and valid estimates of failure probabilities using expert opinion and judgment. NUREG/CR-2255 (Stillwell, Seaver, and Schwartz, 1982), NUREG/CR-2743 (Seaver and Stillwell, 1983), and NUREG/CR-3688 (Comer, Seaver, Stillwell, and Gaddy, 1984) addressed this need by outlining methods for using expert judgments to arrive at these probabilities. These approaches explicated paired comparison, ranking and rating, direct numerical estimation, and indirect numerical estimation techniques applied to error estimation, with a particular emphasis on aggregating the estimates from multiple experts.

Prior guidance for expert elicitation can be extracted from the NUREGs described above. Seminal guidance on conducting expert elicitation comes from NUREG/CR-5424 (Meyer and Booker, 1990). However, these methods do not necessarily reflect ASP requirements. It is desirable to simplify existing formal procedures and guidelines to meet the time constraints and rigor required to conduct ASP analyses.

In the past, the ASP program has informally sought the opinion of experts inside and outside the NRC for the determination of failure probabilities. However, the ASP program needs a formal, documented guideline with steps for determining certain Probabilistic Risk Assessment (PRA) input parameters using expert opinion and judgment. These steps must be consistent with formal expert elicitation methodologies but they should be simplified and streamlined as appropriate for producing ASP studies.

The objective of this project was to develop a 
simplified, streamlined expert elicitation guideline with steps to meet the needs of the NRC ASP Program. The steps documented in this report enable the analyst to obtain a failure or error rate estimate based on expert elicitation.

Since Phase III calculations of NRC's Significance Determination Process (SDP) are similar to those used in the ASP Program, the expert elicitation guidelines are also be applicable for the SDP.

The "Simplified Expert Elicitation Guideline for Risk Assessment of Operating Events" documented in this report was derived from interviews with ASP and SDP analysts about best practices and from a review of the expert elicitation literature. It features step-by-step instructions to assist an analyst in arriving at a probabilistic failure estimate using subject matter experts. The steps include:
- A statement of when the guideline is applicable

- Guidance on selecting the types of experts that may be needed for a particular issue

- The steps for conducting the elicitation

- The manner of documenting the input received from experts, including forms for conducting the elicitation

- The specific worksheets for recording and aggregating expert estimates and calculating a failure rate from those estimates

- A checklist that the ASP program can reference as having been followed. 


\section{EXPERT ELICITATION GUIDELINE INSTRUCTIONS}

\subsection{Expert Elicitation Worksheets}

This guideline utilizes a series of worksheets found for carrying out and documenting the expert elicitation process. The worksheets are designed to be self-explanatory for maximal usability. The analyst should, however, carefully consult these instructions before conducting an initial expert elicitation and whenever usage questions arise. For quick reference, Table 2-1 illustrates the appropriate series of worksheets the analyst should use for expert elicitation of hardware failure or human error.

Table 2-1. Appropriate worksheets for expert elicitation.

\begin{tabular}{c|c|c|}
\multicolumn{1}{c}{} & \multicolumn{1}{c}{$\begin{array}{c}\text { Hardware } \\
\text { Failure }\end{array}$} & \multicolumn{1}{c}{$\begin{array}{c}\text { Human } \\
\text { Error }\end{array}$} \\
\cline { 2 - 3 } & Appendix A & Appendix A \\
\cline { 2 - 3 } $\begin{array}{c}\text { Problem } \\
\text { Framing }\end{array}$ & Eppert \\
\cline { 2 - 3 } $\begin{array}{c}\text { Expert } \\
\text { Elicitation }\end{array}$ & Appendix B & $\begin{array}{c}\text { SPAR-H } \\
\text { Worksheets }\end{array}$ \\
\cline { 2 - 3 } $\begin{array}{c}\text { Estimate } \\
\text { Aggregation }\end{array}$ & Appendix C & Appendix D \\
\cline { 2 - 3 } $\begin{array}{c}\text { Elicitation } \\
\text { Checklist }\end{array}$ & Appendix E & Appendix E \\
\cline { 2 - 3 } & &
\end{tabular}

The expert elicitation guideline for hardware failures utilizes three worksheets, which are found in Appendices A - C. The analyst conducting the expert elicitation should complete these worksheets as a way of documenting the key steps and calculations involved in the expert elicitation. Worksheet $\mathrm{A}$ is for use in framing the problem to be presented to experts. Worksheet B documents the expert's failure or error rate estimate and the basis for that estimate. Worksheet $\mathrm{C}$ is for use in aggregating the individual estimations into a single failure rate for use in probabilistic risk assessment (PRA).

If the analyst is determining a human error probability (HEP), he or she should instead utilize the appropriate Standardized Plant Analysis Risk Human Reliability Analysis (SPAR-H) worksheets for at-power or low power and shutdown. These worksheets may be found in the SPAR-H NUREG (Gertman et al., in press). Aggregation of SPAR-H estimates should be documented using the worksheet in Appendix D.

Appendix E serves as a checklist for both hardware failure and human error elicitations to ensure that all steps, including providing supporting materials, have been completed.

\subsection{Requirements}

The requirements provided here outline the boundary conditions for this expert elicitation guideline. These requirements can be classified into two different types. The first set of requirements outline when and on what types of problems it is appropriate to use this expert elicitation guideline. The second set of requirements outline how the results of the process can be used.

\subsubsection{Requirements for When and on What Problems to Use This Guideline}

These requirements describe the necessary entry conditions for when the analyst is initially considering the use of this guideline. Before 
proceeding with an analysis, it is necessary to review the available history about the event and plant type, known failure probabilities, and the current generation PRA models for the plant type and event scenario. This review will determine the unknowns in the event and the questions that need to be answered in order to arrive at a failure rate for the event.

\section{$\checkmark \quad$ Expert elicitation should only be implemented if additional vetted sources of information cannot adequately inform a hardware failure or human error rate.}

The analyst should check to see if there are previous analyses related to the event. The starting point for the current analysis is to check the assumptions, modeling, calculations, and expert estimations from any previous analysis. A previous analysis may render expert elicitation unnecessary or significantly simplify the work involved in expert elicitation. Nonetheless, it is necessary to verify and validate the existing analysis before incorporating it into the new analysis.

Identification of additional information sources is usually a straightforward process, depending on the nature of that additional data source. These data sources include:

- Event reports. Including Licensee Event Reports (LERs) and Augmented Inspection Team (AIT) reports. These may be reviewed for plant-specific information or trended across plants to determine failure rates.

- Research studies. Both public and internal NRC research studies may provide insights into specific event scenarios. When these studies are readily available, they may eliminate the need to elicit expert estimations. In some cases, experts may help to identify relevant research. In rare cases, when the event is highly significant and when there is insufficient empirical basis for expert estimation, the NRC may commission research studies to determine event likelihoods.

- Vendor data. For component related events, any available vendor data regarding reliability should be considered. The analyst may wish to contact the vendor to determine the availability of specific data.

- Licensee/operating data. The analyst may review licensee operating data to trend circumstances leading up to an event. While the precursors may not have been reportable events, they may outline the historical progression leading up to the event in question.

- Available test data. Previous reports and other NRC sources should be reviewed to determine whether existing test data characterize the event.

For information sources that contain previously collected and recorded data, the decision process for identifying and using them in the analysis is as follows:

- Determine what type of data would be helpful in clarifying what the probability estimate would be.

- Obtain data sources and review their content.

- If the additional data sources clarify the probability estimate, it is generally unnecessary to proceed with an expert elicitation. 


\section{$\checkmark$ Only risk significant events warrant expert elicitation.}

If insufficient prior information is available to arrive at a failure rate, the analyst should review the risk significance of the potential failure event to determine the need for expert elicitation. The analyst is to employ standard PRA approaches to determine the risk significance of the component failure or human error. The three most commonly employed measures are the Fussell-Vesely, Birnbaum, and Risk Achievement Worth (RAW). Other techniques may also be used as appropriate. If the issue results in a change in core damage frequency (CDF) that is small (i.e., $\triangle \mathrm{CDF} \leq$ $1 \mathrm{E}-6)$, it is not necessary to proceed with expert elicitation.

Thus, the initial entry requirements for this expert elicitation guideline are that it should be used only for risk significant events for which additional vetted sources of information cannot adequately inform a failure rate.

\subsubsection{Requirements for How the Results May Be Used}

How the results may be used also constrains this expert elicitation guideline. What follows are requirements for application of this guideline.

One applicability requirement can be characterized by the following questions:

- How will the results be used?

- What is the intended application of the results that are generated?

\footnotetext{
$\checkmark$ An appropriate use of expert elicitation is to provide estimates on new, rare, complex, or otherwise poorly
}

\section{understood phenomena.}

An inappropriate use of expert elicitation is as a substitute for data that would otherwise be derived from experimental or operational data. Any use of expert elicitation in place of experimental or operational data must be qualified and accounted for accordingly.

\subsection{Expert Elicitation for Hardware}

\subsubsection{Overview}

Figure 2-1 summarizes the steps for conducting expert elicitation for hardware failure probabilities. The analyst determines that the requirements for expert elicitation are met, frames the problem, identifies the appropriate experts, conducts the expert elicitation with individual experts, convenes a panel of these experts, arrives at a consensus or aggregated estimate, and incorporates the estimate into the risk analysis.

\subsubsection{Frame Problem}

It is critical to provide all experts with the same information about the scenario and to ensure that all experts are attempting to understand the same problem. The expert must be told how the opinion will be used so that the most appropriate estimate is provided.

Below are the steps to be taken when framing the problem to ensure that all experts receive the same information. The analyst should document these steps using the worksheet in Appendix A. 


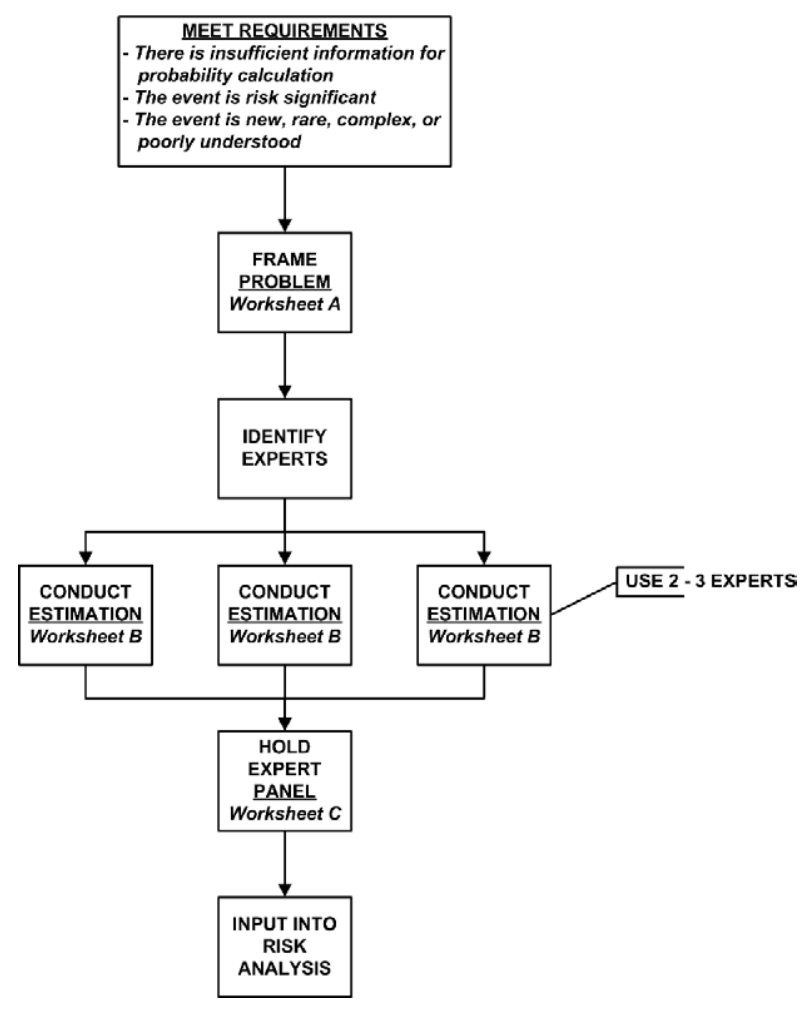

Figure 2-1. Expert elicitation flow diagram for potential hardware failures.

- Determine the type of problem under analysis. Problem types may be actual hardware failures or human errors, or they may be latent hardware failures or human errors that could have resulted in failure or error had they been undetected.

- Summarize the problem. The summary of the problem should be a succinct statement about the problem in question and its importance to overall plant safety.

- Provide background material and supporting documentation. Provide relevant case histories from the plant or similar events. Licensee supplied information may be provided when available. The subsystems and components that make up that high level system should be listed. Any historical information regarding the reliability of the subsystems or components should be included.

- Provide a summary of results from the initial analysis, including the estimated CDF (when available). Experts may not be familiar with the concept of CDF, and it may be necessary to explain this information to experts. The initial analysis may include nominal or default failure rates for components, which serve as a useful baseline against which experts can estimate the failure rate for the specific incident.

- Define assumptions. The problem summary should make as explicit as possible what is to be included and what is to be excluded, such as whether the analyst should consider seismic activity, dependency, functional recovery, or common cause failures.

- Provide a concise statement regarding the information required from the expert. The expert should know exactly what he or she is being required to estimate.

\subsubsection{Identify the Experts}

This section provides guidance on the process by which appropriate experts are identified.

In many cases, the analyst may know appropriate experts to contact within or outside of the NRC. However, in other cases, it may be necessary to solicit input from subject matter experts who are not known by the analyst. How does the analyst determine who these experts are, and how can the analyst ensure that these experts are qualified to provide estimates? Currently, there is no database or directory of experts related to 
nuclear power plants. Absent such a directory, below are several suggestions for identifying appropriate experts.

The analyst should always begin by framing the problem (see Section 2.3.2). Determining the problem domain is the cornerstone of matching the event to an expert.

For the purposes of ASP analyses, it is recommended that no fewer than two experts but preferably three experts be consulted. SDP analyses may utilize a single expert where time constraints prohibit use of multiple experts (see Section 2.5). By definition, the use of multiple experts attenuates the effect of any single expert's bias. Using multiple experts therefore increases the scrutability of the analysis of the event. NUREG/CR-5424 (Meyer and Booker, 1990) suggests one technique to attenuate bias is to select more than one expert using a stratified random sampling method-a method of sampling in which the experts are selected from different sources (e.g., national lab experts, academics, NRC experts, etc.).

The expert elicitation process presented in this report has been optimized for use with two to three subject matter experts.

- Except in the case of certain SDP analyses, it is never recommendable to utilize a single expert, because there is the inherent danger that the selection of that single expert may not reflect the true distribution of opinions for the particular problem domain. Selection of a single expert may result in inaccurate and non-replicable probability estimates.

- In cases of high-risk uncertainty (i.e., CDF $\geq 1 \mathrm{E}-4$ ), in which the analysis warrants the use of three or more experts or a multidisciplinary team of experts, it is recommended that the analyst follow the steps outlined in NUREG/CR-5424 (Meyer and Booker, 1990), which provide a comprehensive treatment of expert elicitation methods that are suitable for large-scale elicitations.

In the absence of a directory of experts for the particular problem domain, it is necessary to identify likely sources of experts. Common sources include in-house NRC subject matter experts, experts from the national lab sector, industry experts, licensees, academics, and vendors. Effective strategies for identifying subject matter experts include the following methods identified by current NRC analysts:

- Ask other SDP or ASP analysts for their recommendations on suitable experts.

- When trying to identify an expert, it may be necessary to drill up or down the organizational hierarchy to find a match for the problem domain. For example, when searching for in-house NRC subject matter experts, the NRC's online organization charts provide limited detail regarding all staff members in a particular division. The organization chart may point to specific Branch Chiefs, who may serve as a preliminary point of contact for determining specific experts within their branch. Similarly, when searching for experts within the national lab sector, it may be possible to contact managers within relevant groups identified from the online departmental Web pages or organization charts.

- An expert may serve as a point of contact to further experts. For example, an expert from the national lab sector may know of qualified experts in the academic sector. 
When using known experts to recommend further experts, it is especially important to ensure that the new experts represent an unbiased sample of available experts by using the correction methods for selection bias described in NUREG/CR-5424 (i.e., stratified random sampling).

- All things being equal, it is important to choose experts who have an existing relationship with the NRC and are regularly employed to support NRC activities. Currently, there is no mechanism for funding experts who consult on an analysis but who are not otherwise employed through the NRC.

After candidate experts have been identified, the NRC analyst should make initial contact with the experts to determine experts who are qualified, willing, and able to participate in an expert elicitation. In many cases, the initial contact may proceed directly to the expert elicitation process (see Section 2.3.4). The analyst should be prepared to conduct the estimation process at the point of contacting the expert by having Worksheets A and B available to give to the expert. In no case should experts be contacted prior to completion of Worksheet A.

\subsubsection{Conduct the Expert Elicitation}

During the expert elicitation, the analyst works individually with each expert to arrive at the estimated rate of failure. It is crucial that all experts be provided the same information. Therefore, it is required that all experts receive a written copy of Worksheet A for the framed problem developed in Section 2.3.2.

The preferred form of contact between the analyst and individual expert is face-to-face. Face-to-face communication is the most efficient way of eliciting estimations when the expert is in close proximity to the analyst. This method would be particularly appropriate when using in-house NRC subject matter experts. If face-to-face communication is not possible, a telephone conversation or video conference is also an efficient way for the expert to convey the estimation after seeing the framed problem. As a last resort, written electronic communication such as faxes, emails, letters, and instant messaging may be employed. With the exception of instant messaging, these methods do not afford the analyst the opportunity to clarify communications in real-time, thus introducing potential confounds in the quality of the elicitation.

The analyst records the product of the elicitation using Worksheet B. The steps are as follows.

The analyst describes to the expert the issue, challenge, or problem for which the expert's judgment is needed and describes the salient and unique features and characteristics of the problem as developed in Section 2.3.2 and documented in Worksheet A.

The expert provides his or her name and affiliation. In some cases, the expert may chose to remain anonymous regarding public release of the elicitation. However, identifying the expert provides the preferred level of public accountability and traceability required for a scrutable risk analysis.

- The expert should clarify the nature of his or her expertise specifically as it pertains to the issue, challenge, or problem. 
- The analyst asks the expert to reflect back their understanding of the issue, challenge, or problem. The nature of the issue, challenge, or problem, as understood by the analyst should reasonably match the expert's understanding. If there is a mismatch, the analyst may note new insights gained through the expert and use them during the expert panel (see Section 2.3.5), or the analyst may clarify deficits in the expert's understanding of the issue, challenge, or problem.

- The expert should provide, in an openended form, factors and assumptions that are relevant to the problem. For example, the expert may draw on past personal experience or past operating experience. The expert should also qualify any restrictions on the applicability of past personal or operating experience to the current problem domain. This information serves to pedigree the estimate.

- The expert should provide an estimate of failure likelihood equivalent to the $50^{\text {th }}$ and $95^{\text {th }}$ percentile points on a probability distribution. The analyst should ask this question in terms of the median and upper bound values. If the expert is unfamiliar with this casting of the failure rate, the analyst should phrase the question in terms of the worst case and typical case scenarios. For the worst case, the expert should provide the maximum percentage of time that the hardware could fail (which is equivalent to the $95^{\text {th }}$ percentile case), followed by the typical case or the percentage of time that the hardware will typically fail (which is equivalent to the $50 \%$ case).

The likelihood of failure can be expressed as a probability (e.g., 1\%, $10 \%$ ), a decimal (e.g., $0.001,0.1$ ), or a ratio (e.g., 1/1000, 1/5). The analyst may wish to explain that the "best" estimate will be used as a median value. The median value can be viewed as an estimate at which point the expert believes there is a $50 \%$ chance the "true" value is in fact higher than the expert might guess (and a 50\% chance the "true" value is lower). The upper bound estimate can be viewed as an estimate at which point the expert believes there is a strong likelihood ( $95 \%$ chance) that the "true" value will be lower than his or her estimate (and only a 5\% chance that the "true" value is higher).

These two numbers will later allow the analyst to construct a beta or comparable distribution from the estimate. Note that it is not necessary to collect the lower bound $5^{\text {th }}$ percentile case, since this represents the percentage of the time that the hardware will almost never fail, a measure that is akin to successful hardware operation, not hardware failure.

Note that the analyst could reverse the order of the data pedigree and probability estimation steps, but the literature on expert elicitation has shown that prematurely forcing the expert to translate their judgment or opinion into quantitative expressions has been a problem with past attempts at expert elicitation.

The simplified expert elicitation guideline in this document does not attempt to calibrate 
individuals to scale or distribution use by providing brief training on probabilistic estimation. Previous research has shown that scale calibration is time consuming (Boring, 2004) and may produce only nominal advantages over using the $50^{\text {th }}$ and $95^{\text {th }}$ percentile cases (O'Hagan and Oakley, 2004).

Upon completion of Worksheet B for an expert, the analyst provides a copy of the worksheet to the expert for review and verification. The analyst should carefully review the expert input and clarify any misunderstandings or open-ended issues identified during the review of Worksheet B. The expert, in turn, should discuss any necessary changes or revisions with the analyst.

\subsubsection{Convene Expert Panel}

When all expert estimates agree within a factor of three, it is typically not necessary to convene an expert panel. The analyst should then proceed directly to Section 2.3.6 on aggregating the data.

If the estimates in Worksheet B vary by more than a factor of three, the analyst convenes a panel of all of the experts for discussion of the estimates. The desired format for this panel is face-to-face, but it is possible to substitute teleconferencing or videoconferencing. It is important that the panel is convened relatively soon after the individual elicitations (i.e., typically within one week) in order to keep the estimation process fresh in the experts' minds.

The panel discussion has two portions, which utilize Worksheet C.

- First, the analyst presents a brief summary of each expert estimation as provided in Worksheet B. The summary is kept brief. Each expert is encouraged to refrain from commenting until all estimation summaries have been presented by the analyst. The analyst also presents the average of the individual estimates to facilitate discussion.

- Next, the analyst acts as the moderator for the group discussion. The goal of the discussion is to clarify the individual estimations, discuss similarities and differences, and arrive at a consensus between the experts for the $50^{\text {th }}$ and $95^{\text {th }}$ percentile probability values. Worksheet $\mathrm{C}$ allows the analyst to summarize main points of the discussion. The analyst must exercise care to ensure that the discussion ensues as a productive exchange of information related to the analysis. Opinions may differ considerably, but the tone of the discussion should remain centered on the analysis, not on the validity of individual expert estimations or the credibility of individual experts.

Each expert should be given the opportunity to modify his or her individual estimation worksheet throughout the panel to reflect additional information obtained as a result of the panel discussion.

A sample agenda for the panel meeting is presented in Table 2-2. Following the sample agenda in Table 2-2, for a typical panel discussion comprised of three experts, the analyst would host a one-hour expert panel meeting. Even if there is disparity of opinions such that it proves impossible for the experts to arrive at a consensus estimate, the analyst should openly note this disagreement and conclude the meeting within the agreed upon 
meeting time period.

Table 2-2. Sample agenda for panel discussion.

\begin{tabular}{|c|c|}
\hline Analyst: & Introduction to topic and experts ( 5 mins.) \\
\hline Analyst: & $\begin{array}{l}\text { Summary of each expert's estimation ( } 5 \\
\text { mins. per expert) }\end{array}$ \\
\hline Experts: & $\begin{array}{l}\text { Questions and discussion to clarify } \\
\text { estimations ( } 5-10 \text { mins.) }\end{array}$ \\
\hline Experts: & Discussion of issues (10-15 mins.) \\
\hline Experts: & Consensus discussion (10 - 15 mins.) \\
\hline Analyst: & Summary of issues and resolution ( 5 mins.) \\
\hline
\end{tabular}

At the conclusion of the panel discussion, there are two likely outcomes:

- The experts reach a reasonable consensus on the $50^{\text {th }}$ and $95^{\text {th }}$ percentile failure rates.

- There is disagreement between the experts, and only a partial consensus or no consensus is reached on the $50^{\text {th }}$ and $95^{\text {th }}$ percentile failure rates.

In both cases, any dissenting opinion should be noted on Worksheet C. When there is consensus of the estimate within a factor of three across the experts, the median of these values is used directly in the PRA, without further refinement. ${ }^{1}$ When there is less than perfect consensus, as is expected to be the case frequently, it is necessary to use a mathematical aggregation of individual expert

\footnotetext{
${ }^{1}$ Note that the consensus estimate does not take into account the fact that a consensus reached from a large panel has greater certainty (i.e., has tighter uncertainty bounds) than a consensus reached from a small panel. However, the effect of any difference in panel size is negligible when using the recommended number of experts. Within the recommended applicability of this guideline to panels of two to three experts, no correction is necessary.
}

estimations.

\subsubsection{Aggregate Estimates}

A simple aggregation technique is provided in Worksheet C. In this approach, the expected value $(E)$ is computed across experts for the median $(\mathrm{m})$ or $50^{\text {th }}$ percentile probability of failure and the upper $(u)$ bound or $95^{\text {th }}$ percentile rate of failure. $E$ is computed as the mean or average of the individual experts' values. The arithmetic mean $(E)$ is computed in the standard fashion:

$E=\frac{\sum_{i=1}^{N} x_{i}}{N}$

where $x_{\mathrm{i}}$ represents the values to be averaged and $N$ represents the total number of values. The arithmetic mean produces slightly more conservative failure rates than the geometric mean, and, by definition, the geometric mean is always equal to or smaller than the arithmetic mean. The analyst may make use of the geometric mean when there are strong reasons or preferences to do so. This use of the geometric instead of arithmetic mean should be noted on the aggregation worksheet.

The expected value is computed for both the median $\left(E_{m}\right)$ and upper bound $\left(E_{u}\right)$. Worksheet $\mathrm{C}$ includes places to record both values.

\subsubsection{Compute Distribution and Input into Risk Model}

A beta distribution is assumed as input in the risk model, because it conforms to the requirements for a probability distribution (with bounds of 0 and 1) and because it affords the flexibility to approximate different 
distribution shapes including uniform, normal, and lognormal distributions. A beta distribution is frequently used in risk analysis to model uncertainty in probability. This is due in part to the fact that the beta distribution may be easily derived from the median and upper bound values.

The beta distribution requires two parameters, $\alpha$ and $\beta$, to arrive at the appropriate distribution. These parameters can be readily computed from the $50^{\text {th }}$ and $95^{\text {th }}$ percentile values resulting from expert elicitation consensus or aggregation.

Since there is no closed form for this calculation, the $\alpha$ and $\beta$ values are best obtained using a solver program that contains a function for calculating cumulative probability distributions for the beta distribution. Specialty software may be utilized, as may readily available software such as Microsoft Excel. For illustrative purposes, Appendix F describes the steps required to use Microsoft Excel to compute $\alpha$ and $\beta$.

The $\alpha$ and $\beta$ parameters serve to define the distribution suitable for inclusion in PRA models. For example, using SAPHIRE, the analyst would select the beta distribution and would supply the $\alpha$ and $\beta$ values to allow SAPHIRE to compute the hardware failure rate with corresponding uncertainty.

Note that some analysts may prefer using the lognormal distribution because it is widely used and understood. The beta distribution is the preferred distribution, because it affords simplicity to the guideline by closely approximating the lognormal and other distributions. Nonetheless, an analyst who prefers the lognormal may still make use of the included worksheets. The lognormal distribution requires two input parameters-the error factor $(E F)$ and the lognormal mean-both of which may be easily calculated from the $50^{\text {th }}(\mathrm{m})$ and $95^{\text {th }}(u)$ percentile values. $\mathrm{EF}$ is simply $u / m$, while the lognormal of the mean is simply:

$$
\ell N(\text { mean })=\exp \left(\mu+\frac{\sigma^{2}}{2}\right),
$$

where

$$
\mu=\log (m),
$$

and

$$
\sigma=\frac{\log (E F)}{1.645} .
$$

Note that care should be exercised not to exceed the probabilistic upper bound of 1 . The analyst should consider using the logistic normal (logit) or truncated lognormal distributions and corresponding functions to ensure bounding within 0 and 1 .

Other distributions are possible for use in expert elicitation but are beyond the scope of this guideline.

\subsection{Expert Elicitation for Human Error}

\subsubsection{Overview}

The process of conducting expert elicitation for human error mirrors the process for hardware error outlined in Section 2.3, with the exception that the SPAR-H worksheets 
serve as the basis of the estimation. ${ }^{2}$ A detailed discussion of the appropriate use of the SPAR$\mathrm{H}$ worksheets is beyond the scope of this guideline. Analysts should refer to the SPARH NUREG (Gertman et al., in press) for thorough guidance on the proper assignment of SPAR-H performance shaping factors (PSFs) to arrive at a human error probability (HEP).

Figure 2-2 summarizes the steps for conducting expert elicitation for human error probabilities using the SPAR-H worksheets. The process differs from the process for hardware in only a few ways:

- In framing the problem using Worksheet A, particular emphasis should be paid to supply any available information that could help in the determination of the eight SPAR-H PSFs. The analyst should carefully provide any relevant documentation on human performance that will aid the experts in assigning the PSF levels. If the experts are not familiar with SPAR-H quantification, it is important that the analyst attach a description of the SPAR-H PSFs (see SPAR-H NUREG, Chapter 2) and a description of the SPAR-H process (see SPAR-H N UREG, Chapter 4).

${ }^{2}$ The SPAR-H method is itself a streamlined method. There may be cases in which the list of performance shaping factors or the simplified dependency calculations do not fully meet the requirements for the risk analysis. In such cases, the analyst should consult other HRA methods. Several of these methods are outlined in the SPAR-H NUREG (Gertman et al., in press).

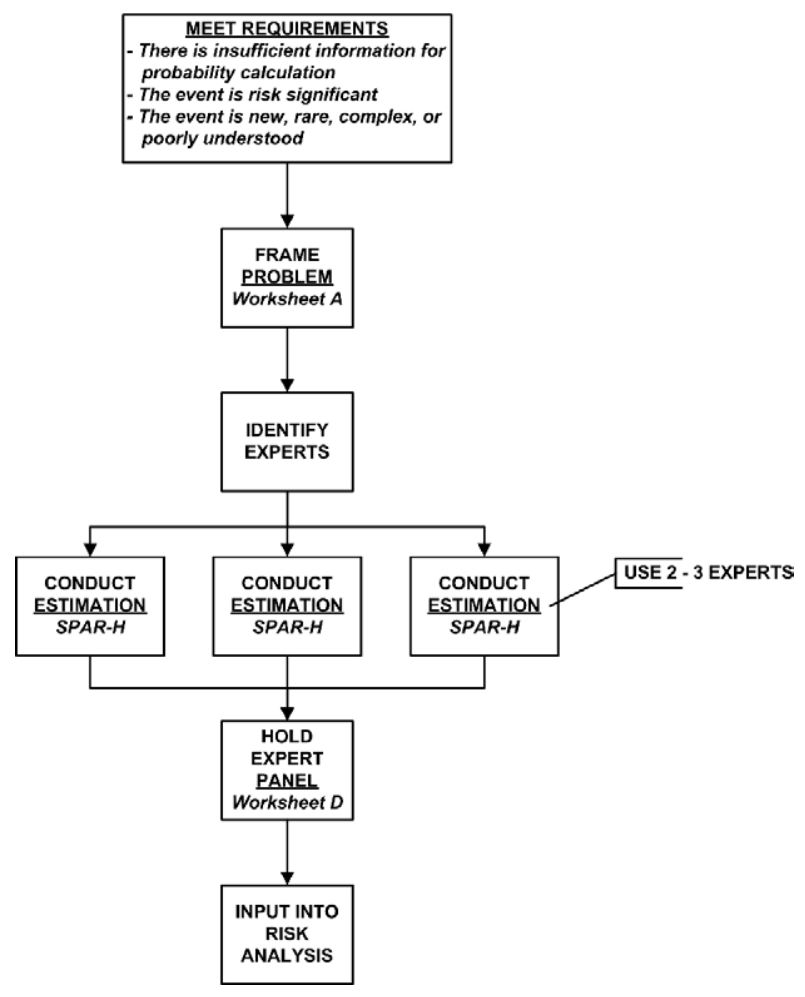

Figure 2-2. Expert elicitation flow diagram for human error probabilities.

- In identifying experts, it is important to consult appropriate human factors or operations experts, who are generally better qualified than hardware experts to gauge the correct assignment of PSF levels.

The analyst should determine the appropriate SPAR-H worksheet. If the problem domain applies to an atpower situation at a plant, the atpower worksheet (SPAR-H Appendix A) should be utilized. If the problem domain applies to a low power or shutdown situation at a plant, the low power/shutdown (LP/SD) worksheet (SPAR-H Appendix B) should be used to document the elicitation. Specific information that the expert provides in 
terms of guiding his or her assignment of PSF levels should be recorded on the worksheets.

- Because the SPAR-H worksheets constrain the response of the experts, it is generally possible to allot a shorter time frame for the expert panel meeting. Table $2-3$ provides a sample agenda for expert panels involving human error conditions.

Table 2-3. Sample agenda for SPAR-H panel discussion.

\begin{tabular}{|ll|}
\hline Analyst: & Introduction to topic and experts (5 mins.) \\
Analyst: & $\begin{array}{l}\text { Summary of each expert's estimation (5 } \\
\text { mins. per expert) }\end{array}$ \\
Experts: & $\begin{array}{l}\text { Questions and discussion to clarify } \\
\text { estimations (5 mins.) }\end{array}$ \\
& Discussion of issues (5 - 10 mins.) \\
Experts: & Consensus discussion (5 - 10 mins.) \\
Experts: & Summary of issues and resolution (5 mins.) \\
Analyst: & .
\end{tabular}

- In most cases, it will be possible for experts to arrive at a consensus for the appropriate PSFs, although there may be moderate disagreement on the proper level of PSF assignments. When differences exist for PSF assignments, HEPs should be calculated for each PSF assignment level so that the resultant range of HEP values can be noted in Worksheet D, the Human Error Aggregation Worksheet for SPAR-H. PRA tools such as SAPHIRE allow the analyst to record the weighting of each PSF assignment. For example, if two experts decide on a particular PSF assignment and one expert decides on a slightly different PSF assignment, it is possible to weight the PSF levels $67 \%$ and $33 \%$, respectively.

- SPAR-H does not provide lower or upper uncertainty bounds. Thus, the
HEP serves as the sole input into the PRA model. The constrained noninformative prior distribution (Atwood, 1996), a variation of the beta distribution when uncertainty bounds are not available, should be used for incorporating SPAR-H HEPs into SAPHIRE PRA models.

- In rare circumstances, there may be disagreement between experts in the selection of the appropriate level of dependency between multiple events. When such disagreement occurs, it should be noted in the aggregation worksheet and the HEP values with dependency should be averaged across experts.

It is preferable to use PSF level weighting when aggregating disparate expert opinions on human error. If, however, it is necessary to aggregate the HEP values (e.g., if performing a SPAR-H analysis without SAPHIRE), the arithmetic average of the individual experts' overall HEP values serves as appropriate input to the PRA model when using the constrained noninformed prior distribution.

\subsection{Notes on SDP, ASP, and Other NRC Elicitation Requirements}

While this expert elicitation guideline is designed to crosscut both SDP and ASP analyses, there are a number of special considerations when performing an SDP analysis.

A key difference between SDP and ASP analyses is the time allowed for the individual 
analysis. Whereas an ASP analyst may use up to a year to complete an analysis, an SDP analyst is expected to complete the analysis within 90 days. This limited time duration may necessitate slight abridgements to the expert elicitation process:

- $\quad$ An ASP analysts generally has more available time to review all possible data sources, utilizing expert elicitation only as a last resort. Because of time constraints, the SDP analyst may occasionally use expert elicitation as a means to gather relevant background information about an event. In such a case, the expert estimation may be entirely derived from available data sources instead of expert opinion.

- Occasionally, the ASP analyst may formally convene an expert panel of three or more experts for gathering insights into an event. The SDP analyst does not have adequate time for large-scale expert panels.

- Similarly, due to time constraints, the SDP analyst may sometimes rely on elicitation using only one expert. In such cases, the SDP analyst will not need to make use of the aggregation worksheets, except as required to calculate the probability distribution.

- Typically, the SDP analyst will not require a sensitivity analysis, while the ASP analyst will use a sensitivity analysis to determine the importance of the event to the risk analysis.

While this guideline primarily serves the needs of SDP and ASP analysts, it may also be used across the NRC for a variety of situations requiring probabilistic expert estimation and for which a simplified method is desirable due to time or cost constraints. It is, for example, anticipated that this guideline holds considerable promise for probabilistic research involving the analysis of seismic, fire, and waste removal risks. Expert estimates serve as baseline data until such time as sufficient operating and research data can inform the analysis in these domains. The worksheets offer a rigorous process with sufficient flexibility to serve a variety of risk analysis needs, although individual tailoring may be required (e.g., the screening analysis may not focus on CDF but rather on another criterion).

\subsection{Late-Breaking Information}

Occasionally, additional information related to an event may become available during an SDP or ASP analysis only after the analyst has held the expert panel. If this information is deemed by the analyst to be of significant value potentially to change the outcome of the analysis, the analyst may consider reconvening the expert panel. The analyst should provide the additional information to each expert and discuss with each expert individually whether the new information would change his or her estimation. If yes, the expert should reconvene the panel to allow the experts to discuss the new information and consider a new failure or error rate.

\subsection{Analysis Examples}

Two example elicitations are included in Appendices $\mathrm{G}$ and $\mathrm{H}$. Appendix $\mathrm{G}$ features a hardware elicitation involving two pump experts reviewing an incident at a Pressurized Water Reactor (PWR). Appendix $\mathrm{H}$ features a human error estimation involving two human reliability analysts reviewing an incident at a different PWR. Both examples are analyses of 
actual incidents that have been sanitized for the purposes of inclusion in this guideline. 


\section{REFERENCES}

Atwood, C.L. (1996). Constrained noninformative priors in risk assessment. Reliability Engineering and System Safety, 53, 37-46.

Boring, R.L. (2004). Cognition and Psychological Scaling: Model, Method, and Application of Constrained Scaling. $\mathrm{PhD}$ Dissertation, Carleton University, Ottawa, Canada.

Comer, M.K., Seaver, D.A., Stillwell, W.G., \& Gaddy, C.D. (1984). Generating Human Reliability Estimates Using Expert Elicitation, Volume 1. Main Report, NUREG/CR-3688. Washingtion, DC: US Nuclear Regulatory Commission.

Gertman, D., Blackman, H., Marble, J., Byers, J., Haney, L., \& Smith, C. (In press). The SPAR-H Human Reliability Analysis Method, NUREG/CR-in press. Washington, DC: US Nuclear Regulatory Commission.

Meyer, M. A., \& Booker, J. M. (1990). Eliciting and Analyzing Expert Judgment, A Practical Guide, NUREG/CR-5424. Washington, DC: US Nuclear Regulatory Commission.
O'Hagan, A., \& Oakley, J.E. (2004). Probability is perfect, but we can't elicit it perfectly. Reliability Engineering and System Safety, 85, 239-248.

Seaver, D.A., \& Stillwell, W.G. (1983). Procedures for Using Expert Judgment to Estimate Human Error Probabilities in Nuclear Power Plant Operations, NUREG/CR-2743. Washington, DC: US Nuclear Regulatory Commission.

Stillwell, W.G., Seaver, D.A., \& Schwartz, J.P. (1982). Expert Estimation of Human Error Probabilities in Nuclear Power Plant Operations: A Review of Probability Assessment and Scaling, NUREG/CR-2255. Washington, DC: US Nuclear Regulatory Commission.

US Nuclear Regulatory Commission. (2000). Technical Basis and Implementation Guidelines for A Technique for Human Event Analysis (ATHEANA), NUREG-1624, Rev. 1. Washington, DC: US Nuclear Regulatory Commission. 


\section{APPENDIX A}

\section{EXPERT ELICITATION BACKGROUND INFORMATION WORKSHEET}

Instructions. Complete this worksheet prior to contacting the expert. Provide this worksheet and supporting materials to present the problem domain to the expert. All experts should receive identical information.

1. Analyst's Name and NRC Affiliation:

2. Problem Type: $\quad \square$ Actual Hardware Failure

$\square$ Latent Hardware Failure $\quad \square$ Other:

$\square$ Actual Human Error

$\square$ Latent Human Error

3. Summary of Problem for Analysis:

4. Supporting Documents (Attached):

5. Summary of Results from Initial Analysis:

6. Analysis Assumptions:

7. Information Required from Expert: 
A-2 


\section{APPENDIX B \\ EXPERT ELICITATION WORKSHEET FOR HARDWARE FAILURE}

Instructions. Complete this worksheet for each individual expert. Begin by answering any questions the expert has regarding the problem being analyzed. Then step through each question in sequence. Attach any supporting materials provided by the expert.
1a. Date of Elicitation:
I
1b. Time of Elicitation:
$\square$ A.M. / $\square$ P.M.

2. Expert's Name and Affiliation:
$\square$ In-house NRC
$\square$ Industry Consultant
$\square$ Academia
$\square$ Other:
$\square$ National Lab/DOE
$\square$ Licensee
$\square$ Vendor

3. Expert's Areas of Expertise Relevant to Analysis:

4. Expert's Comments on Problem Under Analysis:

5. Median Failure Rate/ Percent of Time There's a 50/50 Likelihood of Hardware Failure:

50th Percentile Value (Median)

6. Upper Bound/Percent of Time That Hardware Will Almost Certainly Fail:

7. Factors Shaping Expert Estimate:

8. Additional Comments by Expert:

B-1 
B-2 


\section{APPENDIX C}

\section{EXPERT ELICITATION PANEL WORKSHEET FOR HARDWARE FAILURE}

Instructions. Complete this worksheet for the expert panel and data aggregation. Follow instructions in the guideline for facilitating the discussion. Begin by explaining the purpose of the panel, with a goal toward sharing information and arriving at a consensus. Next, read each expert's estimation. Provide the initial aggregation of expert estimates in 3 below. Allow 5 - 10 minutes for questions and another 10 - 15 minutes for discussion. Allow 5 minutes for final discussion and consensus. Allow the experts to modify their individual Worksheet B to incorporate any new information from the discussion.

1a. Panel Conducted? $\square$ Yes/ $\square$ No 1b. Reason:

1c. If NO, Skip to 5

2a. Date of Panel: I

2b. Time of Panel:

$\square$ A.M. / $/$ P.M.

3. Mean of Experts' Median and 95th Percentile Values

4. Summary of Main Points and Issues Raised in Discussion (Including Areas of Disagreement):

5. Consensus Estimate (Within 3x for Median)? $\square$ Yes / $\square$ No

6a. If YES, Record Median of Median and 95th Percentile Values

6b. If NO, Record Mean of Median Estimates and 95th Percentile Values

7. Record Alpha $(\alpha)$ and $\operatorname{Beta}(\beta)$ Values Derived from 6a or $6 b$ for

Beta Distribution or Other Parameters for Non-Beta Distribution: 
C-2 


\section{APPENDIX D}

\section{EXPERT ELICITATION PANEL WORKSHEET FOR SPAR-H}

Instructions. Complete this worksheet for the SPAR-H expert panel and data aggregation. Follow instructions in the guideline for facilitating the discussion. Begin by explaining the purpose of the panel, with a goal toward sharing information and arriving at a consensus. Next, review each expert's SPAR-H worksheets. Discuss PSFs and dependency assumptions that differ between experts. Allow $5-10$ minutes for questions and another $10-15$ minutes for discussion. Allow 5 minutes for final discussion and consensus. Allow the experts to modify their individual SPAR-H worksheets to incorporate any new information from the discussion.

1a. Panel Conducted? $\square$ Yes/ $\square$ No 1b. Reason:

1c. If NO, Goto 4.

2a. Date of Panel: __ _ _ _ 2b. Time of Panel: __ _ _ $\quad$ _ A.M. $/ \square$ P.M.

3. Summary of Main Points and Issues Raised in Discussion Regarding PSF and Dependency Assignments:

4. Experts Agree on a Single SPAR-H HEP Value? $\square$ Yes $/ \square$ No

5a. If YES, Record HEP Constrained Noninformed Prior Distribution.

This Value May be Inserted in SAPHIRE Directly Using the

5b. If NO, Record Mean HEP and on the Next Sheet, Record the Distribution of PSF Assignments Across Experts. This Distribution May be Inserted into SAPHIRE. 
5c. Record Distribution of PSF Assignments Across Experts for Diagnosis and Action SPAR-H Worksheets. Record the Percentage of Experts Who Assigned Each Level.

DIAGNOSIS

\begin{tabular}{|c|c|c|}
\hline PSFs & PSF Levels & $\begin{array}{l}\text { Percentage } \\
\text { Selected }\end{array}$ \\
\hline \multirow{6}{*}{$\begin{array}{l}\text { Available } \\
\text { Time }\end{array}$} & Inadequate time & \\
\hline & $\begin{array}{l}\text { Barely adequate time }(\approx 2 / 3 \\
x \text { nominal })\end{array}$ & \\
\hline & Nominal time & \\
\hline & $\begin{array}{l}\text { Extra time (between } 1 \text { and } \\
2 x \text { nominal and }>\text { than } 30 \\
\text { min) }\end{array}$ & \\
\hline & $\begin{array}{l}\text { Expansive time }(>2 x \\
\text { nominal and }>30 \mathrm{~min})\end{array}$ & \\
\hline & Insufficient information & \\
\hline \multirow{4}{*}{$\begin{array}{l}\text { Stress } \\
\text { Stressors }\end{array}$} & Extreme & \\
\hline & High & \\
\hline & Nominal & \\
\hline & Insufficient Information & \\
\hline \multirow[t]{5}{*}{ Complexity } & Highly complex & \\
\hline & Moderately complex & \\
\hline & Nominal & \\
\hline & Obvious diagnosis & \\
\hline & Insufficient Information & \\
\hline \multirow{4}{*}{$\begin{array}{l}\text { Experiencel } \\
\text { Training }\end{array}$} & Low & \\
\hline & Nominal & \\
\hline & High & \\
\hline & Insufficient Information & \\
\hline \multirow[t]{6}{*}{ Procedures } & Not available & \\
\hline & Incomplete & \\
\hline & Available, but poor & \\
\hline & Nominal & \\
\hline & $\begin{array}{l}\text { Diagnostic/symptom } \\
\text { oriented }\end{array}$ & \\
\hline & Insufficient Information & \\
\hline \multirow{5}{*}{$\begin{array}{l}\text { Ergonomics/ } \\
\text { HMI }\end{array}$} & Missing/Misleading & \\
\hline & Poor & \\
\hline & Nominal & \\
\hline & Good & \\
\hline & Insufficient Information & \\
\hline \multirow{4}{*}{$\begin{array}{l}\text { Fitness for } \\
\text { Duty }\end{array}$} & Unfit & \\
\hline & Degraded Fitness & \\
\hline & Nominal & \\
\hline & Insufficient Information & \\
\hline \multirow{4}{*}{$\begin{array}{l}\text { Work } \\
\text { Processes }\end{array}$} & Poor & \\
\hline & Nominal & \\
\hline & Good & \\
\hline & Insufficient Information & \\
\hline
\end{tabular}

\section{ACTION}

\begin{tabular}{|c|c|c|}
\hline PSFs & PSF Levels & $\begin{array}{l}\text { Percentage } \\
\text { Selected }\end{array}$ \\
\hline \multirow{6}{*}{$\begin{array}{l}\text { Available } \\
\text { Time }\end{array}$} & Inadecuate time & \\
\hline & $\begin{array}{l}\text { Time available is } \approx \text { the time } \\
\text { required }\end{array}$ & \\
\hline & Nominal time & \\
\hline & $\begin{array}{l}\text { Time available } \geq 5 x \text { the } \\
\text { time required }\end{array}$ & \\
\hline & $\begin{array}{l}\text { Time available is } \geq 50 x \text { the } \\
\text { time required }\end{array}$ & \\
\hline & Insufficient Information & \\
\hline \multirow{4}{*}{$\begin{array}{l}\text { Stress } \\
\text { Stressors }\end{array}$} & Extreme & \\
\hline & High & \\
\hline & Nominal & \\
\hline & Insufficient Information & \\
\hline \multirow[t]{4}{*}{ Complexity } & Highly complex & \\
\hline & Moderately complex & \\
\hline & Nominal & \\
\hline & Insufficient Information & \\
\hline \multirow{4}{*}{$\begin{array}{l}\text { Experience/ } \\
\text { Training }\end{array}$} & Low & \\
\hline & Nominal & \\
\hline & High & \\
\hline & Insufficient Information & \\
\hline \multirow[t]{5}{*}{ Procedures } & Not available & \\
\hline & Incomplete & \\
\hline & Available, but poor & \\
\hline & Nominal & \\
\hline & Insufficient Information & \\
\hline \multirow{5}{*}{$\begin{array}{l}\text { Ergonomics/ } \\
\text { HMI }\end{array}$} & Missing/Misleading & \\
\hline & Poor & \\
\hline & Nominal & \\
\hline & Good & \\
\hline & Insufficient Information & \\
\hline \multirow{4}{*}{$\begin{array}{l}\text { Fitness for } \\
\text { Duty }\end{array}$} & Unfit & \\
\hline & Degraded Fitness & \\
\hline & Nominal & \\
\hline & Insufficient Information & \\
\hline \multirow{4}{*}{$\begin{array}{l}\text { Work } \\
\text { Processes }\end{array}$} & Poor & \\
\hline & Nominal & \\
\hline & Good & \\
\hline & Insufficient Information & \\
\hline
\end{tabular}

5d. If No Consensus Reached on Dependency Assignments, Note Source of Differences and Record Mean HEP from $5 b$. 


\section{APPENDIX E}

\section{EXPERT ELICITATION CHECKLIST}

Instructions. Complete this worksheet to ensure successful completion of all steps in the expert elicitation process. Internal or public release of an expert elicitation using this guideline assumes the analyst has successfully completed this checklist, and it is therefore not necessary to include this checklist. However, if the analyst has not completed all steps in this process, any deviations must be fully disclosed.

1. Entry Conditions for Expert Elicitation Met:

$\square$ Additional sources of information consulted and found inadequate to inform probability

$\square$ Event is risk significant

$\square$ Event is new, rare, complex, or otherwise poorly understood

2. Frame the Problem:

$\square$ Worksheet A completed

$\square$ Supporting documentation included

3. Experts Identified:

$\square$ Use of at least 2 experts

$\square$ Care taken to avoid biased sample of experts

4. Conduct Estimation:

$\square$ Worksheet B or SPAR-H Worksheet completed for each expert

$\checkmark$ Supporting documentation from experts provided (if any)

5. Expert Panel:

$\square$ Expert panel held $\quad$ or $\quad \square$ Expert panel not necessary due to consensus

$\square$ Summary of arguments

noted in Worksheet C

(hardware failure) or $D$

(human error)

6. Aggregation:

$\square$ Aggregation consensus or calculations noted in Worksheet $C$ (hardware failure) or $D$ (human error)

7. Risk Analysis Incorporation:

$\square$ Expert estimate successfully incorporated into PRA model

8. Note any deviations from the requirements in $1-7$ and document in final analysis writeup. 
E-2 


\section{APPENDIX F}

\section{MICROSOFT EXCEL PROBLEM SOLVER FOR BETA DISTRIBUTION PARAMETERS}

This appendix describes how to configure Microsoft Excel XP to compute the $\alpha$ and $\beta$ parameters of a beta distribution from the $50^{\text {th }}$ and $95^{\text {th }}$ percentile values. Similar solvers may be configured in Corel Quattro Pro and other commercial spreadsheet and analysis software. A copy of the Excel Problem Solver spreadsheet may be obtained from the authors of this document or the NRC Program Manager.

In Microsoft Excel, ensure that the Problem Solver is installed. The Solver will appear under the Tools dropdown menu on the main menu bar if it is installed (see Figure F-1).

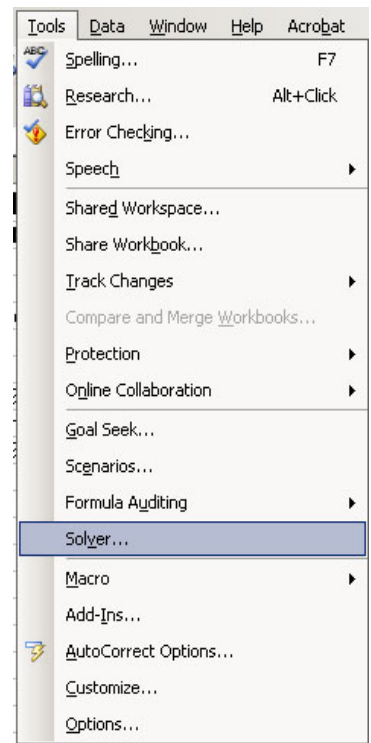

Figure F-1. Tools dropdown menu when the Solver is installed.

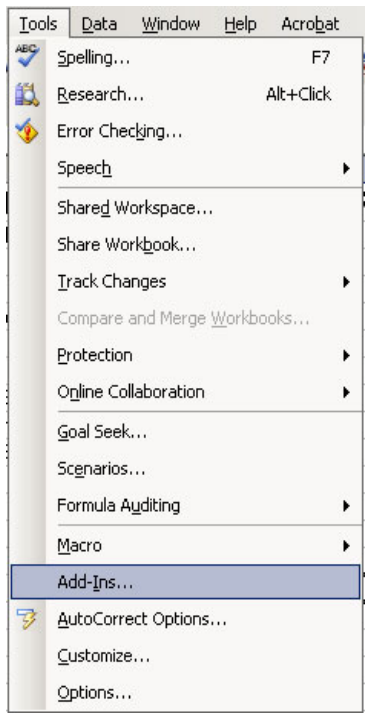

Figure F-2. Add-Ins menu selection under the Tools dropdown menu.

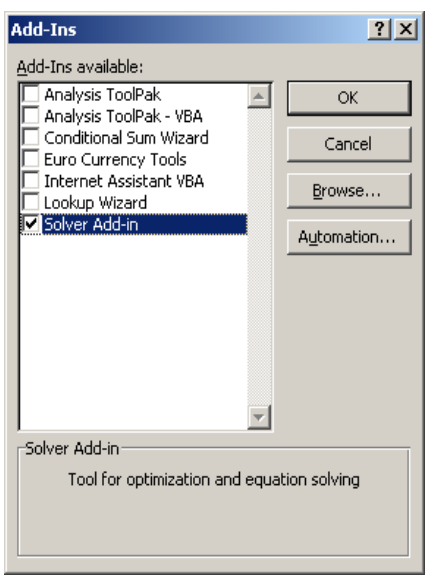

Figure F-3. Add-Ins window with Solver Add-in selected.

If the Solver is not installed, it is necessary to select Add-Ins from the Tools dropdown menu (see Figure F-2). A window entitled "Add-Ins" will appear as in Figure F-3. In this window, check the box next to "Solver Add-in" and press "OK." Excel will install the solver. After the Solver is successfully installed, it will appear in the Tools dropdown menu as in Figure F-1.

The beta distribution problem solver spreadsheet can now be configured to look like Figure F-4. Table F-1 outlines what text should be typed into each spreadsheet cell, along with special formatting settings. 


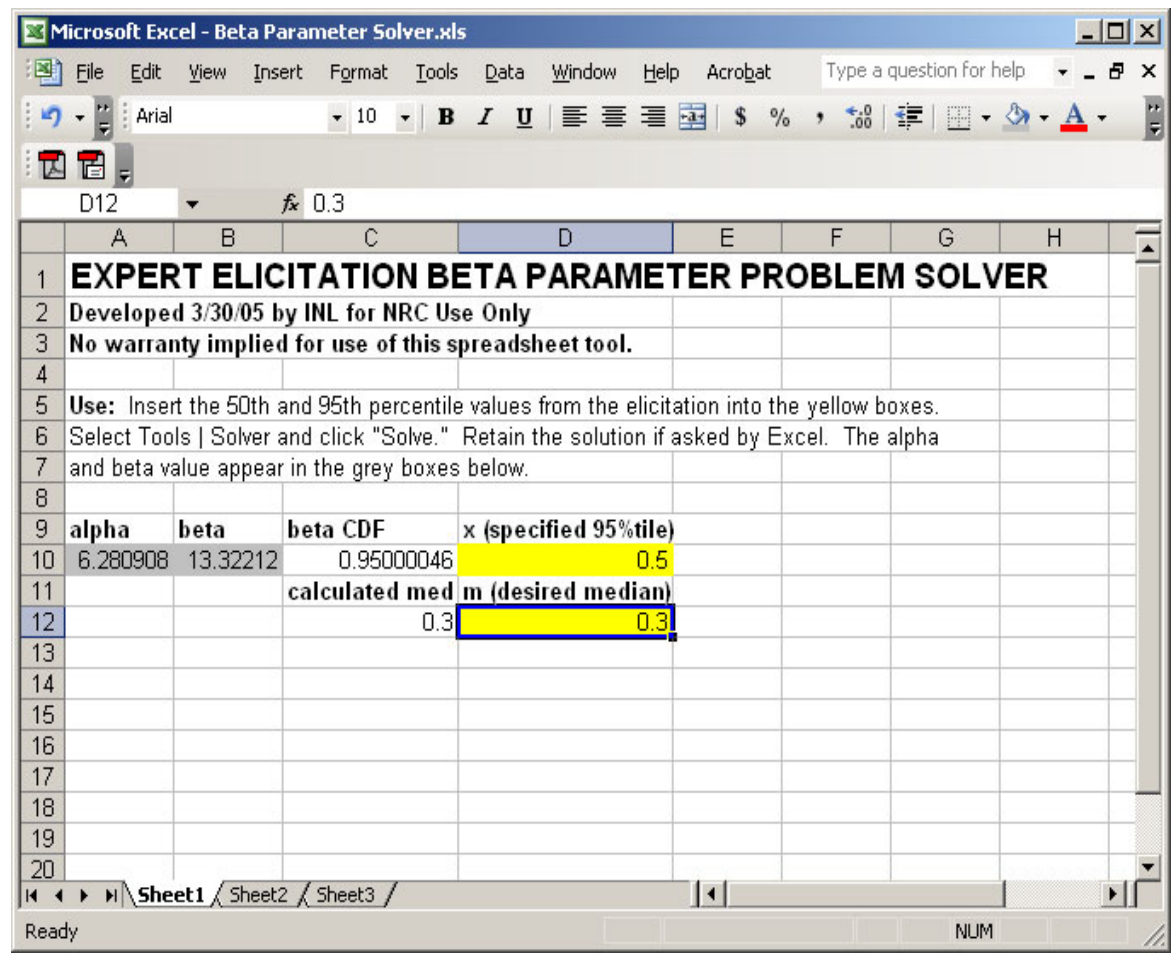

Figure F-4. Screenshot of the Microsoft Excel expert elicitation beta parameter problem solver.

Table F-1. Configuration of spreadsheet.

\begin{tabular}{|c|c|c|}
\hline Cell & Text & Formatting \\
\hline A1 & EXPERT ELICITATION BETA PARAMETER PROBLEM SOLVER & Boldface, Arial Font, Size 14 \\
\hline A2 & Developed 3/30/05 by INL for NRC Use Only & Boldface, Arial Font, Size 10 \\
\hline A3 & No warranty implied for use of this spreadsheet tool. & Boldface, Arial Font, Size 10 \\
\hline A5 & Use: Insert the 50th and 95th percentile values from the elicitation into the yellow boxes. & Arial Font, Size 10, Boldface on "Use:" \\
\hline A6 & Select Tools | Solver and click "Solve." Retain the solution if asked by Excel. The alpha & Arial Font, Size 10 \\
\hline A7 & and beta values appear in the grey boxes below. & Arial Font, Size 10 \\
\hline A9 & alpha & Boldface, Arial Font, Size 10 \\
\hline B9 & beta & Boldface, Arial Font, Size 10 \\
\hline c9 & beta CDF & Boldface, Arial Font, Size 10 \\
\hline D9 & $x$ (specified 95\%tile) & Boldface, Arial Font, Size 10 \\
\hline A10 & $\{$ dummy value between 0 and 1$\}$ & Light Grey Background \\
\hline B10 & $\{$ dummy value between 0 and 1$\}$ & Light Grey Background \\
\hline $\mathrm{C} 10$ & $=\mathrm{BETADIST}(\mathrm{D} 10, \mathrm{~A} 10, \mathrm{~B} 10)$ & Arial Font, Size 10 \\
\hline D10 & 0.5 & Yellow Background \\
\hline C11 & calculated med & Boldface, Arial Font, Size 10 \\
\hline D11 & m (desired median) & Boldface, Arial Font, Size 10 \\
\hline $\mathrm{C} 12$ & $=(\mathrm{A} 10-1) /(\mathrm{A} 10+\mathrm{B} 10-2)$ & Arial Font, Size 10 \\
\hline D12 & 0.3 & Yellow Background \\
\hline
\end{tabular}


Once the spreadsheet has been configured according to Table F-1, it is possible to set the necessary parameters in the Solver. Initiate the Solver by selecting Tools $\mid$ Solver. Configure the fields in the Solver Parameters window exactly as displayed in Figure F-5.

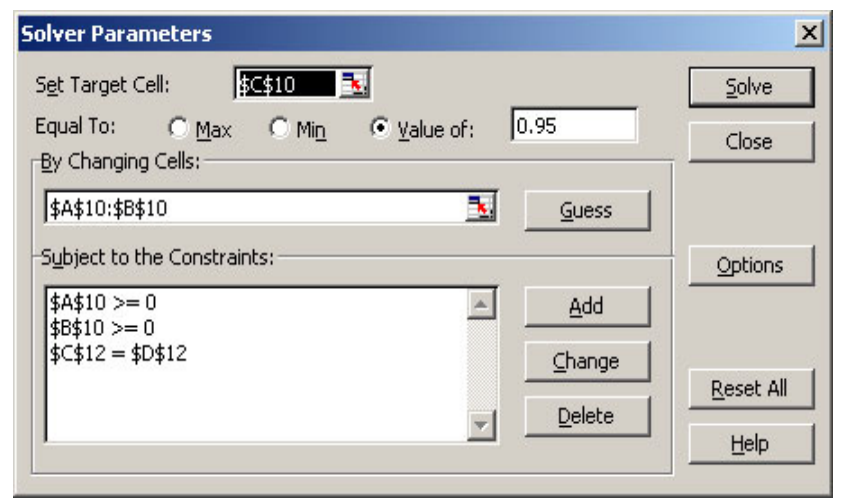

Figure F-5. The Solver Parameters window in Microsoft Excel.

Once the parameters have been input exactly as in Figure F-5, the analyst may press the "Solve" button. The Solver takes the $95^{\text {th }}$ percentile value in Cell D10 and the $50^{\text {th }}$ percentile value in Cell D12 (both demarked by a yellow bakcground) and inserts the computed alpha value into Cell A10 and the beta value into Cell B10 (both of which are demarked by a grey background). To verify that the Solver has correctly arrived at a solution, the beta cumulative distribution function in Cell C10 should approximate 0.95 and the calculated median value in Cell $\mathrm{C} 12$ should approximate the actual median value in Cell D12.

Note that the Solver works by adjusting values in cells A10 and B10 until it arrives at a solution. The analyst should insert a dummy value between 0 and 1 into each of these cells. If the Solver cannot arrive at a solution, it may sometimes be necessary to insert different dummy values in these cells.

Once the Solver has initially been configured, it is not necessary to reconfigure the parameters each time it is activated to solve for alpha and beta values.

If it is necessary to configure a solver in software other than Microsoft Excel, the following definitions set up the necessary conditions for computing $\alpha$ and $\beta$ from the median $(m)$ and the upper probabilty bound $(x)$ :

- $\quad$ Let $\alpha$ and $\beta$ be the two beta distribution parameters

- $\quad$ Let $m=$ the desired median value ( $50^{\text {th }}$ percentile value) for the event probability

- $\quad$ Let $x=$ the desired upper bound $\left(95^{\text {th }}\right.$ percentile value $)$ for the event probability

- $\quad$ Let $p=$ cumulative beta probability distribution function for $x$ given $\alpha$ and $\beta$

Allow the solver to find $\alpha$ and $\beta$ such that $p=0.95$, subject to the constraints: 
- $\quad \alpha>0$

- $\beta>0$

- $\quad \frac{\alpha-1}{\alpha+\beta-2}=m$

The Solver will compute the values of $\alpha$ and $\beta$ that best map the estimated $m$ and $x$ values provided by the experts. 


\section{APPENDIX G}

\section{EXPERT ELICITATION EXAMPLE FOR HARDWARE}

The following example involves an incident at a PWR, in which air was found to be entrained in the suction line of the High Pressure Safety Injection (HPSI) pumps. In particular, air in the line from the emergency containment sump to the HPSI pump suction could have resulted in the failure of the HPSI pumps to operate if there had been an actual (emergency) demand for the pumps to operate. The LER, the SDP final analysis, and supplemental background information provided by the plant about the incident were provided to two pump experts, one affiliated with the INL and the other affiliated with the Idaho Completion Project. The worksheets are included for illustrative purposes. The specific LER, SDP final analysis, and plant background information have been omitted from this guideline in order to conceal the identity of the plant.

The experts reached consensus on the median failure rate, as defined by agreement within three orders of magnitude on the median value. By definition, it was not necessary to conduct an expert panel, and their estimates were mathematically aggregated. However, the experts did not reach consensus on the upper bound values. An analyst might, time permitting, find it fruitful to conduct the panel to determine a potential consensus value on the upper bound. 


\section{EXPERT ELICITATION BACKGROUND INFORMATION WORKSHEET}

Instructions. Complete this worksheet prior to contacting the expert. Provide this worksheet and supporting materials to present the problem domain to the expert. All experts should receive identical information.

1. Analyst's Name and NRC Affiliation: William Galyean, INL

2. Problem Type: _Actual Hardware Failure

3. Summary of Problem for Analysis: Air was found to be entrained in the suction line of the High Pressure Safety Injection (HPSI) pumps. In particular, the line from the emergency containment sump to the HPSI pump suction. This could have resulted in the failure of the HPSI pumps to operate if there had been an actual (emergency) demand for the pumps to operate.

\section{Supporting Documents (Attached):}

LER

proprietary Q\&A

licensee report

SDP final analysis

5. Summary of Results from Initial Analysis: This is judged to be a risk significant issue.

6. Analysis Assumptions: The HPSI system is designed to provide emergency coolant to the reactor pressure vessel (RPV) given a loss of coolant accident. If the reactor cooling system were to lose coolant, the HPSI system would take water from the refueling water storage tank (RWST) and inject that water directly into the RPV. Water lost from the reactor cooling system would collect on the floor of the containment building and collect in the emergency containment sump. Once the water in the RWST reached a low level, the HPSI system automatically re-aligns such that the HPSI pump suction draws from the containment sump instead of the RWST (this is commonly referred to as recirculation mode of operation, versus the injection mode when HPSI takes water from the RWST and injects it into the RPV).

7. Information Required from Expert: Given a demand for the HPSI pumps to operate in the recirculation mode, what is the conditional probability that the pumps will fail to run. The conditions are those described in the event description (as best as they can be interpreted), and assuming a real demand to operate is generated. This is a probabilistic exercise not a deterministic one. Many uncertainties, unknowns, and variations exist on the event and postulated demand. Try to consider the full range of possibilities when making your estimate of the likelihood of failure. The likelihood of failure can be expressed as a probability (e.g., 1\%, 10\%), a decimal (e.g., 0.001, 0.1), or a ratio (e.g., 1/1000, 1/5). Two estimates will be requested from you (the expert). A "best" estimate, which will be used as a median value. And, an upper bound estimate. The Median value can be viewed as an estimate at which point you believe there is a $50 \%$ chance the "true" value is in fact higher than want you guess (and a 50\% chance the "true" value is lower). The upper bound estimate can be viewed as an estimate at which point you believe there is a strong likelihood (95\% chance) that the "true" value will be lower than your estimate (and only a 5\% chance that the "true" value is higher). 


\section{EXPERT ELICITATION WORKSHEET FOR HARDWARE FAILURE}

Instructions. Complete this worksheet for each individual expert. Begin by answering any questions the expert has regarding the problem being analyzed. Then step through each question in sequence. Attach any supporting materials provided by the expert.

1a. Date of Elicitation: $6 / 22 / 2005$

1b. Time of Elicitation: 09:00 am - 09:25 am

2. Expert's Name and Affiliation: Steven R. Smith, Idaho National Laboratory

\begin{tabular}{llll} 
In-house NRC & - Industry Consultant & - Academia & - Other: \\
\hline$\underline{X}$ National Lab/DOE & - Licensee & -Vendor &
\end{tabular}

3. Expert's Areas of Expertise Relevant to Analysis: Fluid-mechanical system engineer at a nuclear test reactor (Advanced Test Reactor at the INL).

4. Expert's Comments on Problem Under Analysis: There are a lot of uncertainties surrounding the details of the event. It would be useful to have information on such things as specific pump design (including the type of bearings used in the pump), and information on the amount of vibration observed during the testing performed.

5. Median Failure Rate/ Percent of Time There's a 50/50 Likelihood of Hardware Failure: $10 \%$ 50th Percentile Value (Median)

6. Upper Bound/Percent of Time That Hardware Will Almost Certainly Fail: $20 \%$ 95th Percentile Value (Upper Bound)

7. Factors Shaping Expert Estimate: Expert listed the following factors as influencing his estimate.

1. Testing might not have accurately modeled the air bubbles (negative influence)

2. Bearings in the pump were assumed by expert to be frictionless

(negative influence with respect to this situation).

3. Maintenance was assumed to be good

4. Air bubbles seemed to be well dispersed and separate (positive influence)

5. Potential transient associated with the air passing-through pump appeared to be short (positive influence)

6. Pump already running when ingestion of air would occur (positive influence).

7. Pumps are 8-stage pumps (positive influence)

8. Additional Comments by Expert: None

G-3 


\section{EXPERT ELICITATION WORKSHEET FOR HARDWARE FAILURE}

Instructions. Complete this worksheet for each individual expert. Begin by answering any questions the expert has regarding the problem being analyzed. Then step through each question in sequence. Attach any supporting materials provided by the expert.

1a. Date of Elicitation: 6/23/2005 1b. Time of Elicitation: $12: 30 \mathrm{pm}-01: 10 \mathrm{pm}$

2. Expert's Name and Affiliation: Daryl Lopez, Idaho Completion Project

\begin{tabular}{llll} 
In-house NRC & - Industry Consultant & - Academia & Other: \\
\hline$\underline{X}$ National Lab/DOE & - Licensee & -Vendor &
\end{tabular}

3. Expert's Areas of Expertise Relevant to Analysis: Mechanical engineer specializing in fluid system design.

4. Expert's Comments on Problem Under Analysis: Pump performance depends on three factors: hydraulics of pump operation, mechanical issues of pump operation, and the details of the downstream demand (i.e., postulated break size).

However, the mechanical issue is judged to not be a concern in this situation due to a short transient time, and the hydraulics will be a function of break size (and the backpressure upstream of the pump).

5. Median Failure Rate/ Percent of Time There's a 50/50 Likelihood of Hardware Failure: $\quad 25 \%$

50th Percentile Value (Median)

6. Upper Bound/Percent of Time That Hardware Will Almost Certainly Fail:

$90 \%$

95th Percentile Value (Upper Bound)

7. Factors Shaping Expert Estimate: The hydraulics associated with the downstream demand will determine whether the pump works or not. Therefore, the predominant influence on pump performance is the postulated break size. There will be a threshold break size such that for smaller breaks the air will affect the pump's operability (air binding will occur), and for larger breaks the air will not (no air binding). This threshold will most likely be at a break size between 2 and 6-inches. The above estimates represent average pump failure probabilities regardless of break size.

8. Additional Comments by Expert: This expert relied upon the empirical data generated by the licensee, and comments on that licensee data by the NRC. 


\section{EXPERT ELICITATION PANEL WORKSHEET FOR HARDWARE FAILURE}

Instructions. Complete this worksheet for the expert panel and data aggregation. Follow instructions in the guideline for facilitating the discussion. Begin by explaining the purpose of the panel, with a goal toward sharing information and arriving at a consensus. Next, read each expert's estimation. Provide the initial aggregation of expert estimates in 3 below. Allow $5-10$ minutes for questions and another 10 - 15 minutes for discussion. Allow 5 minutes for final discussion and consensus. Allow the experts to modify their individual Worksheet $B$ to incorporate any new information from the discussion.

1a. Panel Conducted? $\square$ Yes $/ \otimes$ No 1b. Reason: Experts' median value $<3 x$ different

1c. If NO, Skip to 5

2a. Date of Panel: I

2b. Time of Panel: :_ $\square$ A.M. $/ \square$ P.M.

3. Mean of Experts' Median and 95th Percentile Values

4. Summary of Main Points and Issues Raised in Discussion (Including Areas of Disagreement):

5. Consensus Estimate (Within 3x for Median)? $\otimes$ Yes $/ \square$ No

6a. If YES, Record Median of Median $15 \%$ and 95th Percentile $57.5 \frac{0}{\circ}$ Values

6b. If NO, Record Mean of Median Estimates and 95th Percentile Values

7. Record Alpha $(\alpha) \quad 1.6248$ and Beta $(\beta) \_4.5403 \quad$ Values Derived from 6a or 6b for Beta Distribution or Other Parameters for Non-Beta Distribution: 
G-6 


\section{APPENDIX H}

\section{EXPERT ELICITATION EXAMPLE FOR HUMAN ERROR}

The following example involves an incident at a PWR, in which a steam generator tube ruptured, yielding flow from the primary to secondary system. The cause of this rupture was attributable to poor resolution of condensor vacuum pump degradation coupled with a manual workaround for a failed automatic pressure control valve for the main condenser steamjet air ejector. An LER, Augmented Inspection Team (AIT) Report, and a timeline were provided by the analyst to two HRA experts at the INL. The worksheets are included for illustrative purposes. The specific LER and AIT report have been omitted from this guideline in order to conceal the identity of the plant. A timeline prepared by the analyst is included in sanitized form.

The individual expert SPAR-H worksheets are included. Both experts identified the event in question as primarily a diagnosis type event and used the corresponding Diagnosis section of the SPAR-H Atpower worksheets. The experts failed to reach consensus on the PSF and dependency assignments. Thus, the aggregation worksheet uses the mean HEP value of the two expert estimates. 


\title{
EXPERT ELICITATION BACKGROUND INFORMATION WORKSHEET
}

Instructions. Complete this worksheet prior to contacting the expert. Provide this worksheet and supporting materials to present the problem domain to the expert. All experts should receive identical information.

1. Analyst's Name and NRC Affiliation: Ronald L. Boring, INL

\section{Problem Type: _Actual Hardware Failure

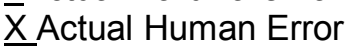

\author{
Latent Hardware Failure \\ _Latent Human Error
}

Other:

3. Summary of Problem for Analysis: At a PWR while operating at 99\% reactor power, operators manually shut down the unit and declared an alet due to a primary to secondary leak in steam generator. The emergency response organization was activated. Operators began cooling down and depressurizing the reactor coolant system as required by procedures. The steam generator was isolated. Within 30 minutes, the rate of the plant cooldown increased. Pressurizer level could not be maintained greater than 9\%. Operators manually initiated safety injection. Pressure in the reactor coolant system and steam generator was equalized. However, later events caused reactor coolant water to flow into the steam generator secondary side. The cooldown continued, including a transition to the residual heat removal system. The plant was brought to cold shutdown, and the alert was terminated. There was no detectable increase in normal background levels of radioactivity as measured by offsite environmental sampling and monitoring equipment.

\section{Supporting Documents (Attached):}

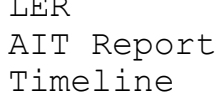

5. Summary of Results from Initial Analysis: This is judged to be a risk significant issue.

6. Analysis Assumptions: Review event timeline as provided to chronicle human actions/inactions that accompanied incident.

7. Information Required from Expert: Complete SPAR-H At-power worksheets for human contribution to failure of steam generator tube rupture. Interested in third human event in timeline: "Automatic pressure control valve for main condensor steamjet air ejector was out of order; licensee decided to operate it in manual mode as a longterm workaround rather than fix the ejector." What is the human error probability for this event? 

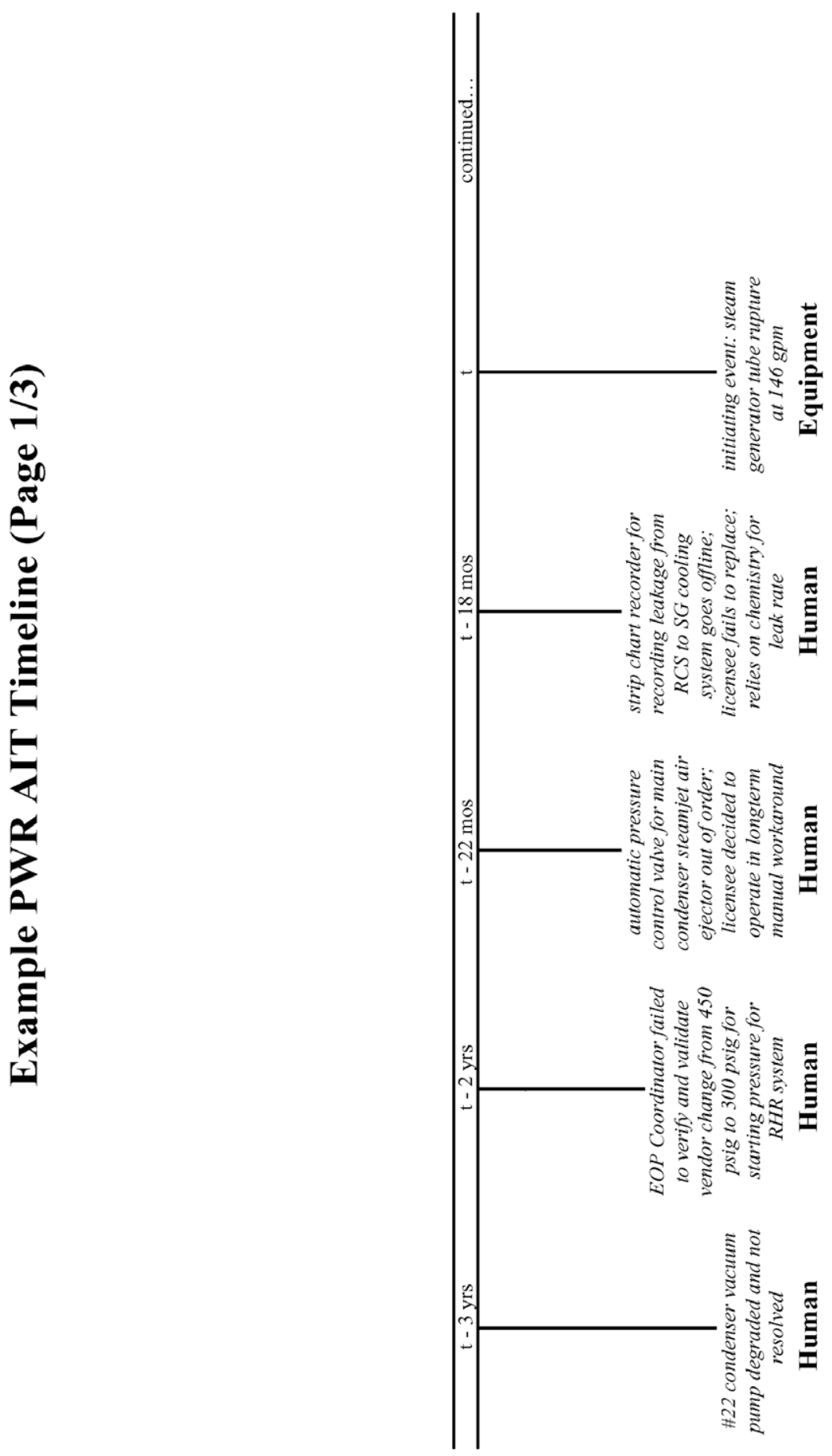


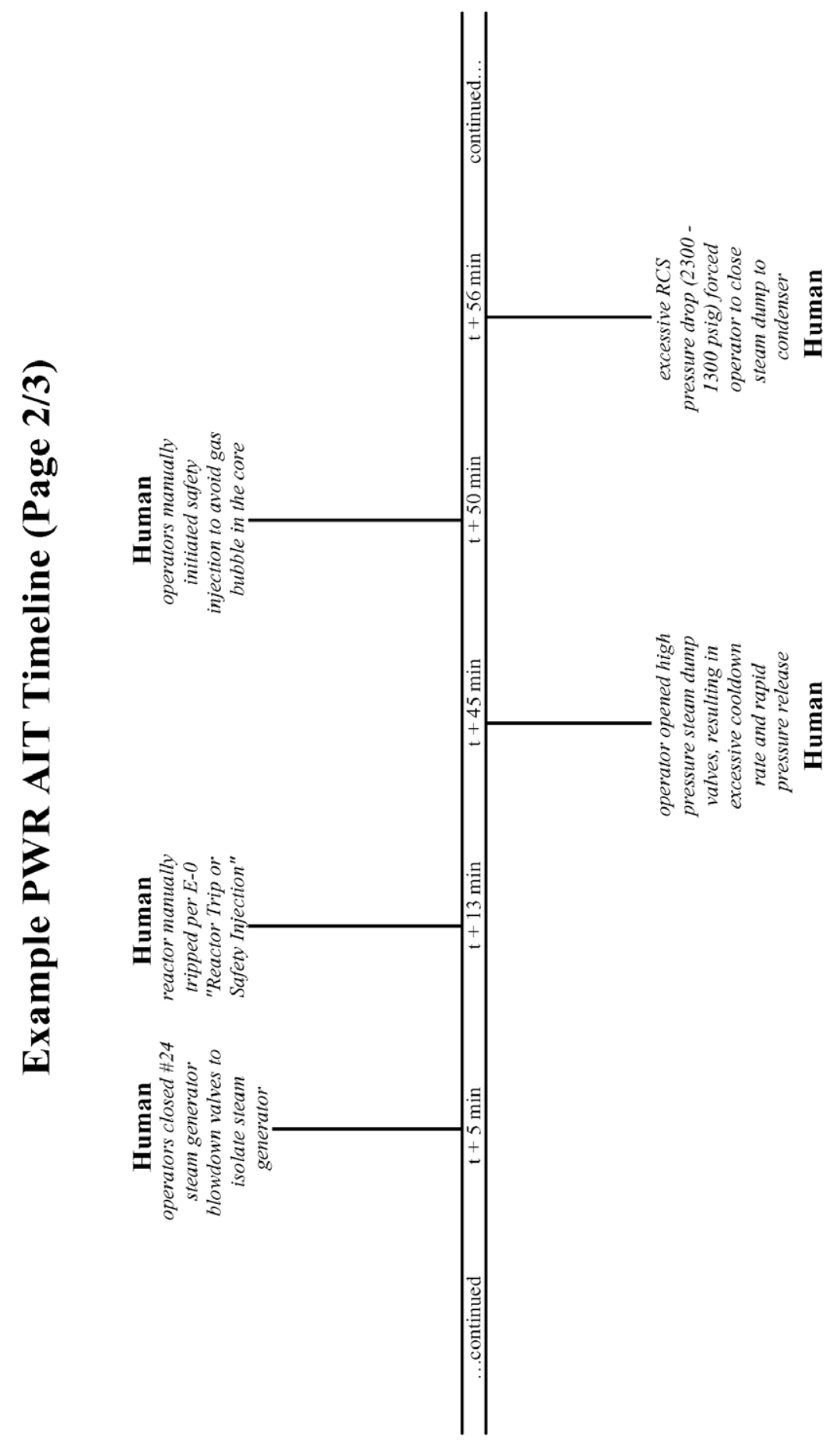




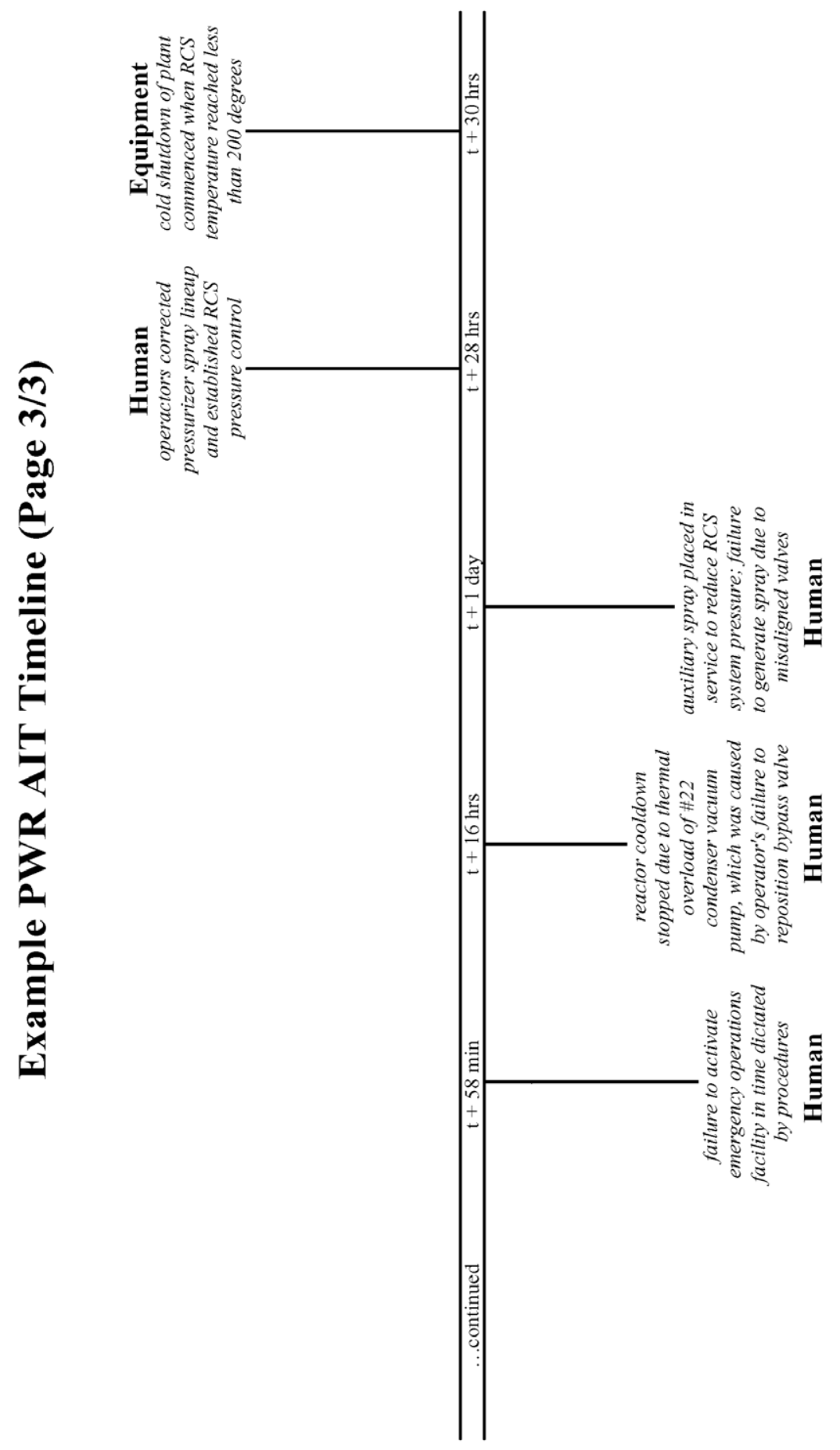




\section{HRA Worksheets for At-Power SPAR HUMAN ERROR WORKSHEET}

Basic Event Description: Automatic pressure control valve for main condensor steamjet air ejector was out of order; licensee decided to operate it in manual mode as a longterm workaround rather than fix the ejector.

Does this task contain a significant amount of diagnosis activity? YES $\otimes$ (start with Part I-Diagnosis) NO $\square$ (skip Part I - Diagnosis; start with Part II-Action) Why? Failure to diagnose correct course of action.

\section{PaRt I. Evaluate EAch PSF for Diagnosis}

A. Evaluate PSFs for the Diagnosis Portion of the Task, If Any.

\begin{tabular}{|c|c|c|c|}
\hline PSFs & PSF Levels & $\begin{array}{l}\text { Multiplier for } \\
\text { Diagnosis }\end{array}$ & $\begin{array}{l}\text { Please note specific reasons for PSF level } \\
\text { selection in this column. }\end{array}$ \\
\hline \multirow{6}{*}{$\begin{array}{l}\text { Available } \\
\text { Time }\end{array}$} & Inadequate time & $\mathrm{P}($ failure $)=1.0 \square$ & \\
\hline & Barely adequate time $(\approx 2 / 3 \times$ nominal $)$ & $10 \quad \square$ & \\
\hline & Nominal time & $\square$ & \\
\hline & $\begin{array}{l}\text { Extra time (between } 1 \text { and } 2 \times \text { nominal and }>\text { than } 30 \\
\text { min) }\end{array}$ & 0.1 & \\
\hline & Expansive time $(>2 \times$ nominal and $>30 \mathrm{~min})$ & 0.01 & \\
\hline & Insufficient information & $\otimes$ & \\
\hline \multirow{4}{*}{$\begin{array}{l}\text { Stress/ } \\
\text { Stressors }\end{array}$} & Extreme & $\square$ & \\
\hline & High & $\square$ & \\
\hline & Nominal & $\square$ & \\
\hline & Insufficient Information & $\otimes$ & \\
\hline \multirow{5}{*}{ Complexity } & Highly complex & $\square$ & \\
\hline & Moderately complex & $\square$ & \\
\hline & Nominal & $\square$ & \\
\hline & Obvious diagnosis & 0.1 & \\
\hline & Insufficient Information & $\otimes$ & \\
\hline \multirow{4}{*}{$\begin{array}{l}\text { Experience/ } \\
\text { Training }\end{array}$} & Low & 10 & \\
\hline & Nominal & $\square$ & \\
\hline & High & 0.5 & \\
\hline & Insufficient Information & $\otimes$ & \\
\hline \multirow[t]{6}{*}{ Procedures } & Not available & 50 & \multirow{6}{*}{$\begin{array}{l}\text { Lack of guidance to solve problem } \\
\text { instead of devising workaround. }\end{array}$} \\
\hline & Incomplete & 20 & \\
\hline & Available, but poor & $\square$ & \\
\hline & Nominal & $\square$ & \\
\hline & Diagnostic/symptom oriented & 0.5 & \\
\hline & Insufficient Information & $\square$ & \\
\hline \multirow{5}{*}{$\begin{array}{l}\text { Ergonomics/ } \\
\text { HMI }\end{array}$} & Missing/Misleading & 50 & \\
\hline & Poor & 10 & \\
\hline & Nominal & $\square$ & \\
\hline & Good & 0.5 & \\
\hline & Insufficient Information & 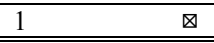 & \\
\hline \multirow{4}{*}{$\begin{array}{l}\text { Fitness for } \\
\text { Duty }\end{array}$} & Unfit & $\mathrm{P}$ (failure) $=1.0 \square$ & \\
\hline & Degraded Fitness & $\square$ & \\
\hline & Nominal & $\square$ & \\
\hline & Insufficient Information & $\otimes$ & \\
\hline \multirow{4}{*}{$\begin{array}{l}\text { Work } \\
\text { Processes }\end{array}$} & Poor & 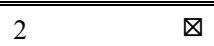 & \multirow{4}{*}{$\begin{array}{l}\text { Organization condones workarounds } \\
\text { instead of fixes. }\end{array}$} \\
\hline & Nominal & $\square$ & \\
\hline & Good & 0.8 & \\
\hline & Insufficient Information & 1 & \\
\hline
\end{tabular}




\section{B. Calculate the Diagnosis Failure Probability.}

(1) If all PSF ratings are nominal, then the Diagnosis Failure Probability $=1.0 \mathrm{E}-2$

(2) Otherwise, the Diagnosis Failure Probability is: 1.0E-2 x Time x Stress or Stressors x Complexity x Experience or Training x Procedures x Ergonomics or HMI x Fitness for Duty x Processes

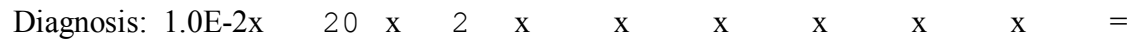

0.4

\section{Calculate the Adjustment Factor IF Negative Multiple ( $\geq 3$ ) PSFs are Present.}

When 3 or more negative PSF influences are present, in lieu of the equation above, you must compute a composite PSF score used in conjunction with the adjustment factor. Negative PSFs are present anytime a multiplier greater than 1 is selected. The Nominal HEP (NHEP) is 1.0E-2 for Diagnosis. The composite PSF score is computed by multiplying all the assigned PSF values. Then the adjustment factor below is applied to compute the HEP:

$H E P=\frac{N H E P \cdot P S F_{\text {composite }}}{N H E P \cdot\left(P S F_{\text {composite }}-1\right)+1}$

Diagnosis HEP with Adjustment Factor $=$

$\mathrm{N} / \mathrm{A}$

D. Record Final Diagnosis HEP.

If no adjustment factor was applied, record the value from Part B as your final diagnosis HEP. If an adjustment factor was applied, record the value from Part $C$.

$$
0.4
$$




\section{Part II. EVALUATE EACH PSF FOR ACTION}

\section{A. Evaluate PSFs for the Action Portion of the Task, If Any.}

\begin{tabular}{|c|c|c|c|c|}
\hline \multirow{2}{*}{$\begin{array}{l}\text { PSFs } \\
\text { Available Time }\end{array}$} & \multirow{2}{*}{$\begin{array}{l}\text { PSF Levels } \\
\text { Inadequate time }\end{array}$} & \multicolumn{2}{|c|}{ Multiplier for Action } & \multirow{7}{*}{$\begin{array}{l}\text { Please note specific reasons for PSF level } \\
\text { selection in this column. }\end{array}$} \\
\hline & & $\mathrm{P}($ failure $)=1.0$ & $\square$ & \\
\hline & Time available is $\approx$ the time required & 10 & $\square$ & \\
\hline & Nominal time & 1 & $\square$ & \\
\hline & Time available $\geq 5 \mathrm{x}$ the time required & 0.1 & $\square$ & \\
\hline & Time available is $\geq 50 \mathrm{x}$ the time required & 0.01 & $\square$ & \\
\hline & Insufficient Information & 1 & $\square$ & \\
\hline \multirow{4}{*}{$\begin{array}{l}\text { Stress/ } \\
\text { Stressors }\end{array}$} & Extreme & 5 & $\square$ & \\
\hline & High & 2 & $\square$ & \\
\hline & Nominal & 1 & $\square$ & \\
\hline & Insufficient Information & 1 & $\square$ & \\
\hline \multirow[t]{4}{*}{ Complexity } & "Highly complex & 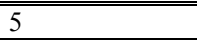 & 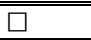 & \\
\hline & Moderately complex & 2 & $\square$ & \\
\hline & Nominal & 1 & $\square$ & \\
\hline & Insufficient Information & 1 & $\square$ & \\
\hline \multirow{4}{*}{$\begin{array}{l}\text { Experience/ } \\
\text { Training }\end{array}$} & Low & 3 & 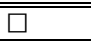 & \\
\hline & Nominal & 1 & $\square$ & \\
\hline & High & 0.5 & $\square$ & \\
\hline & Insufficient Information & 1 & $\square$ & \\
\hline \multirow{5}{*}{ Procedures } & Not available & 250 & $\bar{\square}$ & \\
\hline & Incomplete & 20 & $\square$ & \\
\hline & Available, but poor & 5 & $\square$ & \\
\hline & Nominal & 1 & $\square$ & \\
\hline & Insufficient Information & 1 & $\square$ & \\
\hline \multirow{5}{*}{$\begin{array}{l}\text { Ergonomics/ } \\
\text { HMI }\end{array}$} & Missing/Misleading & 250 & $\square$ & \\
\hline & Poor & 10 & $\square$ & \\
\hline & Nominal & 1 & $\square$ & \\
\hline & Good & 0.5 & $\square$ & \\
\hline & Insufficient Information & 1 & $\square$ & \\
\hline \multirow{4}{*}{$\begin{array}{l}\text { Fitness for } \\
\text { Duty }\end{array}$} & Unfit & $\mathrm{P}($ failure $)=1.0$ & $\square$ & \\
\hline & Degraded Fitness & 5 & $\square$ & \\
\hline & Nominal & 1 & $\square$ & \\
\hline & Insufficient Information & 1 & $\bar{\square}$ & \\
\hline \multirow{4}{*}{$\begin{array}{l}\text { Work } \\
\text { Processes }\end{array}$} & Poor & 25 & $\bar{\square}$ & \\
\hline & Nominal & 1 & $\square$ & \\
\hline & Good & 0.5 & $\square$ & \\
\hline & Insufficient Information & 1 & $\square$ & \\
\hline
\end{tabular}




\section{B. Calculate the Action Failure Probability.}

(1) If all PSF ratings are nominal, then the Action Failure Probability $=1.0 \mathrm{E}-3$

(2) Otherwise, the Action Failure Probability is: 1.0E-3 x Time x Stress or Stressors x Complexity x Experience or Training $\mathrm{x}$ Procedures $\mathrm{x}$ Ergonomics or HMI x Fitness for Duty x Processes

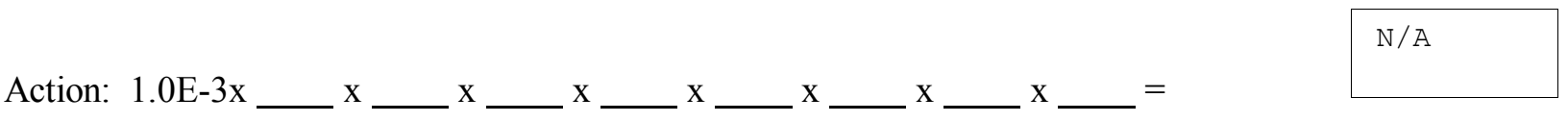

\section{Calculate the Adjustment Factor IF Negative Multiple ( $\geq 3)$ PSFs are Present.}

When 3 or more negative PSF influences are present, in lieu of the equation above, you must compute a composite PSF score used in conjunction with the adjustment factor. Negative PSFs are present anytime a multiplier greater than 1 is selected. The Nominal HEP (NHEP) is 1.0E-3 for Action. The composite PSF score is computed by multiplying all the assigned PSF values. Then the adjustment factor below is applied to compute the HEP:

$H E P=\frac{N H E P \cdot P S F_{\text {composite }}}{N H E P \cdot\left(P S F_{\text {composite }}-1\right)+1}$

Action HEP with Adjustment Factor $=$

\section{Record Final Action HEP.}

If no adjustment factor was applied, record the value from Part B as your final action HEP. If an adjustment factor was applied, record the value from Part C.

Final Action HEP = 


\section{Part III. Calculate Task failure Probability Without Formal Dependence $\left(\mathbf{P}_{\text {w/od }}\right)$}

Calculate the Task Failure Probability Without Formal Dependence $\left(\mathrm{P}_{\mathrm{w} / \mathrm{od}}\right)$ by adding the Diagnosis Failure Probability from Part I and the Action Failure Probability from Part II. In instances where an action is required without a diagnosis and there is no dependency, then this step is omitted.

$$
\mathrm{P}_{\mathrm{w} / \mathrm{od}}=\text { Diagnosis HEP } \_ \text {Action HEP ___ }
$$

\section{Part IV. DEPENDENCY}

For all tasks, except the first task in the sequence, use the table and formulae below to calculate the Task Failure Probability With Formal Dependence $\left(\mathrm{P}_{\mathrm{w} / \mathrm{d}}\right)$.

If there is a reason why failure on previous tasks should not be considered, such as it is impossible to take the current action unless the previous action has been properly performed, explain here:

\section{Dependency Condition Table}

\begin{tabular}{|c|c|c|c|c|c|c|}
\hline $\begin{array}{l}\text { Condition } \\
\text { Number }\end{array}$ & $\begin{array}{c}\text { Crew } \\
\text { (same or } \\
\text { different) }\end{array}$ & $\begin{array}{l}\text { Time } \\
\text { (close in time } \\
\text { or not close } \\
\text { in time) }\end{array}$ & $\begin{array}{l}\text { Location } \\
\text { (same or } \\
\text { different) }\end{array}$ & $\begin{array}{c}\text { Cues } \\
\text { (additional or } \\
\text { no } \\
\text { additional) }\end{array}$ & Dependency & $\begin{array}{c}\text { Number of Human Action Failures Rule } \\
\boldsymbol{\otimes} \text { - Not Applicable. Why? Previous } \\
\text { events spanned years }\end{array}$ \\
\hline 1 & \multirow[t]{8}{*}{$\mathrm{S}$} & \multirow[t]{4}{*}{$\mathrm{c}$} & \multirow[t]{2}{*}{$\mathrm{S}$} & na & complete & \multirow{17}{*}{$\begin{array}{l}\text { When considering recovery in a series } \\
\text { e.g., } 2^{\text {nd }}, 3^{\text {rd }}, \text { or } 4^{\text {th }} \text { checker }\end{array}$} \\
\hline 2 & & & & $\mathrm{a}$ & complete & \\
\hline 3 & & & \multirow[t]{2}{*}{$\mathrm{d}$} & na & high & \\
\hline 4 & & & & $\mathrm{a}$ & high & \\
\hline 5 & & \multirow[t]{4}{*}{ nc } & \multirow[t]{2}{*}{$\mathrm{s}$} & na & high & \\
\hline 6 & & & & $\mathrm{a}$ & moderate & \\
\hline 7 & & & \multirow[t]{2}{*}{$\mathrm{d}$} & na & moderate & \\
\hline 8 & & & & $\mathrm{a}$ & low & \\
\hline 9 & \multirow[t]{8}{*}{$\mathrm{d}$} & \multirow[t]{4}{*}{$\mathrm{c}$} & \multirow[t]{2}{*}{$\mathrm{S}$} & na & moderate & \\
\hline 10 & & & & $\mathrm{a}$ & moderate & \\
\hline 11 & & & \multirow[t]{2}{*}{ d } & na & moderate & \\
\hline 12 & & & & $\mathrm{a}$ & moderate & \\
\hline 13 & & \multirow[t]{4}{*}{ nc } & \multirow[t]{2}{*}{$\mathrm{S}$} & na & $\boldsymbol{V}$ low & \\
\hline 14 & & & & $\mathrm{a}$ & low & \\
\hline 15 & & & \multirow[t]{2}{*}{ d } & na & low & \\
\hline 16 & & & & $\mathrm{a}$ & low & \\
\hline 17 & & & & & zero & \\
\hline
\end{tabular}

Using $\mathrm{P}_{\mathrm{w} / \mathrm{od}}=$ Probability of Task Failure Without Formal Dependence (calculated in Part III):

For Complete Dependence the probability of failure is 1 .

For High Dependence the probability of failure is $\left(1+\mathrm{P}_{\mathrm{w} / \mathrm{d} d}\right) / 2$

For Moderate Dependence the probability of failure is $\left(1+6 \times \mathrm{P}_{\mathrm{w} / \mathrm{od}}\right) / 7$

For Low Dependence the probability of failure is $\left(1+19 \mathrm{x} \mathrm{P}_{\mathrm{w} / \mathrm{od}}\right) / 20$

For Zero Dependence the probability of failure is $P_{w / o d}$

Calculate $\mathrm{P}_{\mathrm{w} / \mathrm{d}}$ using the appropriate values:

$$
\mathrm{P}_{\mathrm{w} / \mathrm{d}}=(1+(19 * 0.4)) / 20=
$$




\section{HRA Worksheets for At-Power SPAR HUMAN ERROR WORKSHEET}

Basic Event Description: Automatic pressure control valve for main condensor steamjet air ejector was out of order; licensee decided to operate it in manual mode as a longterm workaround rather than fix the ejector.

Does this task contain a significant amount of diagnosis activity? YES $\otimes$ (start with Part I-Diagnosis) NO $\square$ (skip Part I - Diagnosis; start with Part II - Action) Why? Conscious decision to workaround.

\section{Part I. Evaluate Each PSF for Diagnosis}

A. Evaluate PSFs for the Diagnosis Portion of the Task, If Any.

\begin{tabular}{|c|c|c|c|c|}
\hline PSFs & PSF Levels & $\begin{array}{l}\text { Mult } \\
\text { Diag }\end{array}$ & & $\begin{array}{l}\text { Please note specific reasons for PSF level } \\
\text { selection in this column. }\end{array}$ \\
\hline \multirow{6}{*}{$\begin{array}{l}\text { Available } \\
\text { Time }\end{array}$} & Inadequate time & \multicolumn{2}{|c|}{$\mathrm{P}($ failure $)=1.0 \square$} & \\
\hline & Barely adequate time $(\approx 2 / 3 \times$ nominal $)$ & 10 & $\square$ & \\
\hline & Nominal time & 1 & 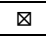 & \\
\hline & $\begin{array}{l}\text { Extra time (between } 1 \text { and } 2 \times \text { nominal and }>\text { than } 30 \\
\text { min) }\end{array}$ & 0.1 & $\square$ & \\
\hline & Expansive time ( $>2 \times$ nominal and $>30 \mathrm{~min})$ & 0.01 & $\square$ & \\
\hline & Insufficient information & 1 & $\square$ & \\
\hline \multirow{4}{*}{$\begin{array}{l}\text { Stress/ } \\
\text { Stressors }\end{array}$} & Extreme & 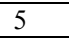 & 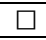 & \\
\hline & High & 2 & $\square$ & \\
\hline & Nominal & 1 & $\nabla$ & \\
\hline & Insufficient Information & 1 & $\square$ & \\
\hline \multirow[t]{5}{*}{ Complexity } & "Highly complex & 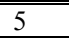 & $\bar{\square} \square$ & \\
\hline & Moderately complex & 2 & $\square$ & \\
\hline & Nominal & 1 & $\otimes$ & \\
\hline & Obvious diagnosis & 0.1 & $\square$ & \\
\hline & Insufficient Information & 1 & $\square$ & \\
\hline \multirow{4}{*}{$\begin{array}{l}\text { Experience/ } \\
\text { Training }\end{array}$} & Low & 10 & $\square$ & \\
\hline & Nominal & 1 & $\otimes$ & \\
\hline & High & 0.5 & $\square$ & \\
\hline & Insufficient Information & 1 & $\square$ & \\
\hline \multirow[t]{6}{*}{ Procedures } & Not available & 250 & 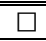 & \multirow{6}{*}{$\begin{array}{l}\text { Decision to operate workaround } \\
\text { rather than fix problem not mediated } \\
\text { by procedures. }\end{array}$} \\
\hline & Incomplete & 20 & $\square$ & \\
\hline & Available, but poor & 5 & $\otimes$ & \\
\hline & Nominal & 1 & $\square$ & \\
\hline & Diagnostic/symptom oriented & 0.5 & $\square$ & \\
\hline & Insufficient Information & 1 & $\square$ & \\
\hline \multirow{5}{*}{$\begin{array}{l}\text { Ergonomics/ } \\
\text { HMI }\end{array}$} & Missing/Misleading & 50 & $\square$ & \multirow{5}{*}{$\begin{array}{l}\text { Automatic valve failed to operate as } \\
\text { prescribed, resulting in manual } \\
\text { workaround. }\end{array}$} \\
\hline & Poor & 10 & $\nabla$ & \\
\hline & Nominal & 1 & $\square$ & \\
\hline & Good & 0.5 & $\square$ & \\
\hline & Insufficient Information & 1 & $\square$ & \\
\hline \multirow{4}{*}{$\begin{array}{l}\text { Fitness for } \\
\text { Duty }\end{array}$} & Unfit & \multicolumn{2}{|c|}{$\mathrm{P}($ failure $)=1.0 \square$} & \\
\hline & Degraded Fitness & 5 & $\square$ & \\
\hline & Nominal & 1 & 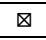 & \\
\hline & Insufficient Information & 1 & $\square$ & \\
\hline \multirow{4}{*}{$\begin{array}{l}\text { Work } \\
\text { Processes }\end{array}$} & Poor & 2 & 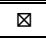 & \multirow{4}{*}{$\begin{array}{l}\text { Workaround is definitionally a poor } \\
\text { work process. }\end{array}$} \\
\hline & Nominal & 1 & $\square$ & \\
\hline & Good & 0.8 & $\square$ & \\
\hline & Insufficient Information & 1 & $\square$ & \\
\hline
\end{tabular}




\section{B. Calculate the Diagnosis Failure Probability.}

(1) If all PSF ratings are nominal, then the Diagnosis Failure Probability $=1.0 \mathrm{E}-2$

(2) Otherwise, the Diagnosis Failure Probability is: 1.0E-2 x Time x Stress or Stressors x Complexity x Experience or Training x Procedures x Ergonomics or HMI x Fitness for Duty x Processes
Diagnosis: $1.0 \mathrm{E}-2 \mathrm{x} \quad 1 \quad \mathrm{x} 1$
$\mathrm{x} 1$

1
$1 \mathrm{x}$
$5 \times 10 \times 1$
x 2

\section{Calculate the Adjustment Factor IF Negative Multiple ( $\geq 3$ ) PSFs are Present.}

When 3 or more negative PSF influences are present, in lieu of the equation above, you must compute a composite PSF score used in conjunction with the adjustment factor. Negative PSFs are present anytime a multiplier greater than 1 is selected. The Nominal HEP (NHEP) is 1.0E-2 for Diagnosis. The composite PSF score is computed by multiplying all the assigned PSF values. Then the adjustment factor below is applied to compute the HEP:

$$
H E P=\frac{N H E P \cdot P S F_{\text {composite }}}{N H E P \cdot\left(P S F_{\text {composite }}-1\right)+1}
$$

Diagnosis HEP with Adjustment Factor $=$

0.5025

\section{Record Final Diagnosis HEP.}

If no adjustment factor was applied, record the value from Part B as your final diagnosis HEP. If an adjustment factor was applied, record the value from Part C. 


\section{Part II. EVALUATE EACH PSF FOR ACTION}

\section{A. Evaluate PSFs for the Action Portion of the Task, If Any.}

\begin{tabular}{|c|c|c|c|c|}
\hline \multirow{2}{*}{$\begin{array}{l}\text { PSFs } \\
\text { Available Time }\end{array}$} & \multirow{2}{*}{$\begin{array}{l}\text { PSF Levels } \\
\text { Inadequate time }\end{array}$} & \multicolumn{2}{|c|}{ Multiplier for Action } & \multirow{7}{*}{$\begin{array}{l}\text { Please note specific reasons for PSF level } \\
\text { selection in this column. }\end{array}$} \\
\hline & & $\mathrm{P}($ failure $)=1.0$ & $\square$ & \\
\hline & Time available is $\approx$ the time required & 10 & $\square$ & \\
\hline & Nominal time & 1 & $\square$ & \\
\hline & Time available $\geq 5 \mathrm{x}$ the time required & 0.1 & $\square$ & \\
\hline & Time available is $\geq 50 \mathrm{x}$ the time required & 0.01 & $\square$ & \\
\hline & Insufficient Information & 1 & $\square$ & \\
\hline \multirow{4}{*}{$\begin{array}{l}\text { Stress/ } \\
\text { Stressors }\end{array}$} & Extreme & 5 & $\square$ & \\
\hline & High & 2 & $\square$ & \\
\hline & Nominal & 1 & $\square$ & \\
\hline & Insufficient Information & 1 & $\square$ & \\
\hline \multirow[t]{4}{*}{ Complexity } & "Highly complex & 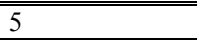 & 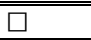 & \\
\hline & Moderately complex & 2 & $\square$ & \\
\hline & Nominal & 1 & $\square$ & \\
\hline & Insufficient Information & 1 & $\square$ & \\
\hline \multirow{4}{*}{$\begin{array}{l}\text { Experience/ } \\
\text { Training }\end{array}$} & Low & 3 & 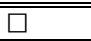 & \\
\hline & Nominal & 1 & $\square$ & \\
\hline & High & 0.5 & $\square$ & \\
\hline & Insufficient Information & 1 & $\square$ & \\
\hline \multirow{5}{*}{ Procedures } & Not available & 250 & $\bar{\square}$ & \\
\hline & Incomplete & 20 & $\square$ & \\
\hline & Available, but poor & 5 & $\square$ & \\
\hline & Nominal & 1 & $\square$ & \\
\hline & Insufficient Information & 1 & $\square$ & \\
\hline \multirow{5}{*}{$\begin{array}{l}\text { Ergonomics/ } \\
\text { HMI }\end{array}$} & Missing/Misleading & 250 & $\square$ & \\
\hline & Poor & 10 & $\square$ & \\
\hline & Nominal & 1 & $\square$ & \\
\hline & Good & 0.5 & $\square$ & \\
\hline & Insufficient Information & 1 & $\square$ & \\
\hline \multirow{4}{*}{$\begin{array}{l}\text { Fitness for } \\
\text { Duty }\end{array}$} & Unfit & $\mathrm{P}($ failure $)=1.0$ & $\square$ & \\
\hline & Degraded Fitness & 5 & $\square$ & \\
\hline & Nominal & 1 & $\square$ & \\
\hline & Insufficient Information & 1 & $\bar{\square}$ & \\
\hline \multirow{4}{*}{$\begin{array}{l}\text { Work } \\
\text { Processes }\end{array}$} & Poor & 25 & $\bar{\square}$ & \\
\hline & Nominal & 1 & $\square$ & \\
\hline & Good & 0.5 & $\square$ & \\
\hline & Insufficient Information & 1 & $\square$ & \\
\hline
\end{tabular}




\section{B. Calculate the Action Failure Probability.}

(1) If all PSF ratings are nominal, then the Action Failure Probability $=1.0 \mathrm{E}-3$

(2) Otherwise, the Action Failure Probability is: 1.0E-3 x Time x Stress or Stressors x Complexity x Experience or Training $\mathrm{x}$ Procedures $\mathrm{x}$ Ergonomics or HMI x Fitness for Duty $\mathrm{x}$ Processes

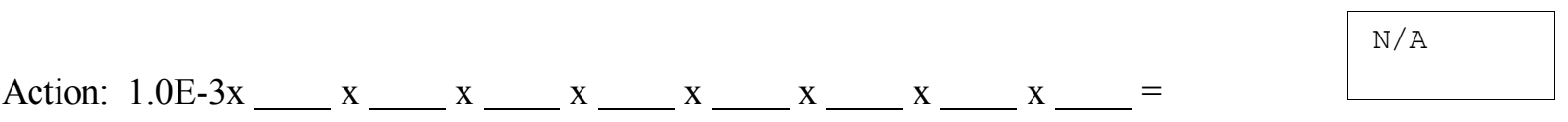

\section{Calculate the Adjustment Factor $\underline{\text { IF }}$ Negative Multiple ( $\geq 3)$ PSFs are Present.}

When 3 or more negative PSF influences are present, in lieu of the equation above, you must compute a composite PSF score used in conjunction with the adjustment factor. Negative PSFs are present anytime a multiplier greater than 1 is selected. The Nominal HEP (NHEP) is 1.0E-3 for Action. The composite PSF score is computed by multiplying all the assigned PSF values. Then the adjustment factor below is applied to compute the HEP:

$H E P=\frac{N H E P \cdot P S F_{\text {composite }}}{N H E P \cdot\left(P S F_{\text {composite }}-1\right)+1}$

Action HEP with Adjustment Factor =

\section{Record Final Action HEP.}

If no adjustment factor was applied, record the value from Part B as your final action HEP. If an adjustment factor was applied, record the value from Part C. 


\section{Part III. Calculate Task failure Probability Without Formal Dependence $\left(\mathbf{P}_{\text {w/od }}\right)$}

Calculate the Task Failure Probability Without Formal Dependence $\left(\mathrm{P}_{\mathrm{w} / \mathrm{od}}\right)$ by adding the Diagnosis Failure Probability from Part I and the Action Failure Probability from Part II. In instances where an action is required without a diagnosis and there is no dependency, then this step is omitted.

$$
\mathrm{P}_{\mathrm{w} / \mathrm{d}}=\text { Diagnosis HEP } \quad .5025+\text { Action HEP } \_0 \quad=0.5025
$$

\section{Part IV. DEPENDENCY}

For all tasks, except the first task in the sequence, use the table and formulae below to calculate the Task Failure Probability With Formal Dependence $\left(\mathrm{P}_{\mathrm{w} / \mathrm{d}}\right)$.

If there is a reason why failure on previous tasks should not be considered, such as it is impossible to take the current action unless the previous action has been properly performed, explain here:

\section{Dependency Condition Table}

\begin{tabular}{|c|c|c|c|c|c|c|}
\hline $\begin{array}{l}\text { Condition } \\
\text { Number }\end{array}$ & $\begin{array}{c}\text { Crew } \\
\text { (same or } \\
\text { different) }\end{array}$ & $\begin{array}{l}\text { Time } \\
\text { (close in time } \\
\text { or not close } \\
\text { in time) }\end{array}$ & $\begin{array}{l}\text { Location } \\
\text { (same or } \\
\text { different) }\end{array}$ & $\begin{array}{c}\text { Cues } \\
\text { (additional or } \\
\text { no } \\
\text { additional) }\end{array}$ & Dependency & $\begin{array}{c}\text { Number of Human Action Failures Rule } \\
\square \text { - Not Applicable. } \\
\text { Why? }\end{array}$ \\
\hline 1 & \multirow[t]{8}{*}{$\mathrm{S}$} & \multirow[t]{4}{*}{$\mathrm{c}$} & \multirow[t]{2}{*}{$\mathrm{S}$} & na & complete & \multirow{17}{*}{$\begin{array}{l}\text { When considering recovery in a series } \\
\text { e.g., } 2^{\text {nd }}, 3^{\text {rd }}, \text { or } 4^{\text {th }} \text { checker }\end{array}$} \\
\hline 2 & & & & $\mathrm{a}$ & complete & \\
\hline 3 & & & \multirow[t]{2}{*}{$d$} & na & high & \\
\hline 4 & & & & $\mathrm{a}$ & high & \\
\hline 5 & & \multirow[t]{4}{*}{$\mathrm{nc}$} & \multirow[t]{2}{*}{$\mathrm{s}$} & na & high & \\
\hline 6 & & & & $\mathrm{a}$ & moderate & \\
\hline 7 & & & \multirow[t]{2}{*}{$\mathrm{d}$} & na & moderate & \\
\hline 8 & & & & $\mathrm{a}$ & low & \\
\hline 9 & \multirow[t]{8}{*}{$\mathrm{d}$} & \multirow[t]{4}{*}{$\mathrm{c}$} & \multirow[t]{2}{*}{$\mathrm{S}$} & na & moderate & \\
\hline 10 & & & & $\mathrm{a}$ & moderate & \\
\hline 11 & & & \multirow[t]{2}{*}{ d } & na & moderate & \\
\hline 12 & & & & $\mathrm{a}$ & moderate & \\
\hline 13 & & \multirow[t]{4}{*}{$\mathrm{nc}$} & \multirow[t]{2}{*}{$\mathrm{s}$} & na & low & \\
\hline 14 & & & & $\mathrm{a}$ & low & \\
\hline 15 & & & \multirow[t]{2}{*}{ d } & na & low & \\
\hline 16 & & & & $\mathrm{a}$ & low & \\
\hline 17 & & & & & zero & \\
\hline
\end{tabular}

Using $\mathrm{P}_{\mathrm{w} / \mathrm{od}}=$ Probability of Task Failure Without Formal Dependence (calculated in Part III):

For Complete Dependence the probability of failure is 1 .

For High Dependence the probability of failure is $\left(1+\mathrm{P}_{\mathrm{w} / \mathrm{d} d}\right) / 2$

For Moderate Dependence the probability of failure is $\left(1+6 \times \mathrm{P}_{\mathrm{w} / \mathrm{od}}\right) / 7$

For Low Dependence the probability of failure is $\left(1+19 \times \mathrm{x}_{\mathrm{w} / \mathrm{od}}\right) / 20$

For Zero Dependence the probability of failure is $\mathrm{P}_{w / o d}$

Calculate $\mathrm{P}_{\mathrm{w} / \mathrm{d}}$ using the appropriate values:

$$
\mathrm{P}_{\mathrm{w} / \mathrm{d}}=(\underline{1}+(\underline{6} * \underline{0.5025})) / \underline{7}=0.5736
$$




\section{EXPERT ELICITATION PANEL WORKSHEET FOR SPAR-H}

Instructions. Complete this worksheet for the SPAR-H expert panel and data aggregation. Follow instructions in the guideline for facilitating the discussion. Begin by explaining the purpose of the panel, with a goal toward sharing information and arriving at a consensus. Next, review each expert's SPAR-H worksheets. Discuss PSFs and dependency assumptions that differ between experts. Allow 5 - 10 minutes for questions and another $10-15$ minutes for discussion. Allow 5 minutes for final discussion and consensus. Allow the experts to modify their individual SPAR-H worksheets to incorporate any new information from the discussion.

1a. Panel Conducted? $\otimes$ Yes/ $\square$ No 1b. Reason: Difference in PSF and dependency assignment 1c. If NO, Goto 4.

2a. Date of Panel: 6/17/2005

2b. Time of Panel: 10:30 $\otimes$ A.M. / P.M.

3. Summary of Main Points and Issues Raised in Discussion Regarding PSF and Dependency

Assignments: Disagreement over applicability of ergonomics PSF. First expert argued that failure of valve to actuate was not consequence of poor ergonomics. Discussion on dependency. Second expert agreed that moderate dependency not absolutely required given long time duration between events in timeline, however some dependency established through history of workarounds. Note that experts agreed that insufficient information and nominal PSF assignments were identical, since both had modifiers equal to 1.

4. Experts Agree on a Single SPAR-H HEP Value? $\square$ Yes $/ \otimes$ No

5a. If YES, Record HEP This Value May be Inserted in SAPHIRE Directly Using the Constrained Noninformed Prior Distribution.

5b. If NO, Record Mean HEP 0.5018 and on the Next Sheet, Record the Distribution of PSF Assignments Across Experts. This Distribution May be Inserted into SAPHIRE. 
5c. Record Distribution of PSF Assignments Across Experts for Diagnosis and Action SPAR-H Worksheets. Record the Percentage of Experts Who Assigned Each Level.

\section{DIAGNOSIS}

\begin{tabular}{|c|c|c|}
\hline PSFs & PSF Levels & $\begin{array}{l}\text { Percentage } \\
\text { Selected }\end{array}$ \\
\hline \multirow{6}{*}{$\begin{array}{l}\text { Available } \\
\text { Time }\end{array}$} & Inadequate time & \\
\hline & $\begin{array}{l}\text { Barely adequate time }(\approx 2 / 3 \\
x \text { nominal) }\end{array}$ & \\
\hline & Nominal time & $100 \%$ \\
\hline & $\begin{array}{l}\text { Extra time (between } 1 \text { and } \\
2 \times \text { nominal and }>\text { than } 30 \\
\text { min) }\end{array}$ & \\
\hline & $\begin{array}{l}\text { Expansive time (>2x } \\
\text { nominal and }>30 \mathrm{~min})\end{array}$ & \\
\hline & Insufficient information & \\
\hline \multirow{4}{*}{$\begin{array}{l}\text { Stress' } \\
\text { Stressors }\end{array}$} & Extreme & \\
\hline & High & \\
\hline & Nominal & \\
\hline & Insufficient Information & 100 \\
\hline \multirow[t]{5}{*}{ Complexity } & Highly complex & \\
\hline & Moderately complex & \\
\hline & Nominal & \\
\hline & Obvious diagnosis & $100 \%$ \\
\hline & Insufficient Information & \\
\hline \multirow{4}{*}{$\begin{array}{l}\text { Experiencef } \\
\text { Training }\end{array}$} & Low & \\
\hline & Nominal & \\
\hline & High & $100 \%$ \\
\hline & Insufficient Information & \\
\hline \multirow[t]{6}{*}{ Procedures } & Not available & \\
\hline & Incomplete & $50 \%$ \\
\hline & Available, but poor & \\
\hline & Nominal & $50 \%$ \\
\hline & $\begin{array}{l}\text { Diagnostic/symptom } \\
\text { oriented }\end{array}$ & \\
\hline & Insufficient Information & \\
\hline \multirow{5}{*}{$\begin{array}{l}\text { Ergonomics: } \\
\text { HMI }\end{array}$} & Missing/Misleading & \\
\hline & Poor & $50 \%$ \\
\hline & Nominal & \\
\hline & Good & \\
\hline & Insufficient Information & $50 \%$ \\
\hline \multirow{4}{*}{$\begin{array}{l}\text { Fitness for } \\
\text { Duty }\end{array}$} & Unfit & \\
\hline & Degraded Fitness & \\
\hline & Nominal & \\
\hline & Insufficient Information & $100 \%$ \\
\hline \multirow{4}{*}{$\begin{array}{l}\text { Work } \\
\text { Processes }\end{array}$} & Poor & \\
\hline & Nominal & $100 \%$ \\
\hline & Good & \\
\hline & Insufficient Information & \\
\hline
\end{tabular}

ACTION

\begin{tabular}{|c|c|c|}
\hline PSFs & PSF Levels & $\begin{array}{l}\text { Percentage } \\
\text { Selected }\end{array}$ \\
\hline \multirow{6}{*}{$\begin{array}{l}\text { Available } \\
\text { Time }\end{array}$} & Inadequate time & \\
\hline & $\begin{array}{l}\text { Time available is } \approx \text { the time } \\
\text { required }\end{array}$ & \\
\hline & Nominal time & \\
\hline & $\begin{array}{l}\text { Time available } \geq 5 x \text { the } \\
\text { time required }\end{array}$ & \\
\hline & $\begin{array}{l}\text { Time available is } \geq 50 x \text { the } \\
\text { time required }\end{array}$ & \\
\hline & Insufficient Information & \\
\hline \multirow{4}{*}{$\begin{array}{l}\text { Stress/ } \\
\text { Stressors }\end{array}$} & Extreme & \\
\hline & High & \\
\hline & Nominal & \\
\hline & Insufficient Information & \\
\hline \multirow[t]{4}{*}{ Complexity } & Highly complex & \\
\hline & Moderately complex & \\
\hline & Nominal & \\
\hline & Insufficient Information & \\
\hline \multirow{4}{*}{$\begin{array}{l}\text { Experience/ } \\
\text { Training }\end{array}$} & Low & \\
\hline & Nominal & \\
\hline & High & \\
\hline & Insufficient Information & \\
\hline \multirow[t]{5}{*}{ Procedures } & Not available & \\
\hline & Incomplete & \\
\hline & Available, but poor & \\
\hline & Nominal & \\
\hline & Insufficient Information & \\
\hline \multirow{5}{*}{$\begin{array}{l}\text { Ergonomics/ } \\
\text { HMI }\end{array}$} & Missing/Misleading & \\
\hline & Poor & \\
\hline & Nominal & \\
\hline & Good & \\
\hline & Insufficient Information & \\
\hline \multirow{4}{*}{$\begin{array}{l}\text { Fitness for } \\
\text { Duty }\end{array}$} & Unfit & \\
\hline & Degraded Fitness & \\
\hline & Nominal & \\
\hline & Insufficient Information & \\
\hline \multirow{4}{*}{$\begin{array}{l}\text { Work } \\
\text { Processes }\end{array}$} & Poor & \\
\hline & Nominal & \\
\hline & Good & \\
\hline & Insufficient Information & \\
\hline
\end{tabular}

\section{5d. If No Consensus Reached on Dependency Assignments, Note Source of Differences and Record} Mean HEP from $5 b$.

Second expert preferred to keep moderate dependency to reflect historic trend of workarounds and poor work processes. Mean HEP $=0.5018$ (Expert $1=0.43$; Expert $2=$ 0.5736 ) 